\title{
Tien Shan geohazards database: Earthquakes and landslides
}

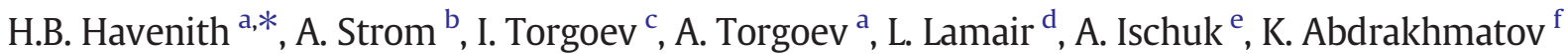 \\ a Department of Geology, University of Liege, Liege, Belgium \\ b Geodynamics Research Center, JSC Hydroproject Institute, Moscow, Russia \\ ${ }^{c}$ Institute of Geomechanics and Development of Subsoil, Acad. of Sciences, Bishkek, Kyrgyzstan \\ d Department of Geography, University of Liege, Liege, Belgium \\ e Institute of Geology, Earthquake Engineering and Seismology, Acad. of Sciences, Dushanbe, Tajikistan \\ ${ }^{\mathrm{f}}$ Institute of Seismology, National Academy of Science, Bishkek, Kyrgyzstan
}

\section{A R T I C L E I N F O}

\section{Article history:}

Received 18 August 2014

Received in revised form 13 January 2015

Accepted 14 January 2015

Available online $\mathrm{xxxx}$

\section{Keywords:}

Giant mass movements

Seismo-tectonic

Size-frequency

Gutenberg-Richter Law

Spatio-temporal

Coupled hazards

Central Asia

\begin{abstract}
A B S T R A C T
In this paper we present new and review already existing landslide and earthquake data for a large part of the Tien Shan, Central Asia. For the same area, only partial databases for sub-regions have been presented previously. They were compiled and new data were added to fill the gaps between the databases. Major new inputs are products of the Central Asia Seismic Risk Initiative (CASRI): a tentative digital map of active faults (even with indication of characteristic or possible maximum magnitude) and the earthquake catalogue of Central Asia until 2009 that was now updated with USGS data (to May 2014). The new compiled landslide inventory contains existing records of 1600 previously mapped mass movements and more than 1800 new landslide data. Considering presently available seismo-tectonic and landslide data, a target region of $1200 \mathrm{~km}$ (E-W) by $600 \mathrm{~km}(\mathrm{~N}-\mathrm{S})$ was defined for the production of more or less continuous geohazards information. This target region includes the entire Kyrgyz Tien Shan, the South-Western Tien Shan in Tajikistan, the Fergana Basin (Kyrgyzstan, Tajikistan and Uzbekistan) as well as the Western part in Uzbekistan, the North-Easternmost part in Kazakhstan and a small part of the Eastern Chinese Tien Shan (for the zones outside Kyrgyzstan and Tajikistan, only limited information was available and compiled).

On the basis of the new landslide inventory and the updated earthquake catalogue, the link between landslide and earthquake activity is analysed. First, size-frequency relationships are studied for both types of geohazards, in terms of Gutenberg-Richter Law for the earthquakes and in terms of probability density function for the landslides. For several regions and major earthquake events, case histories are presented to outline further the close connection between earthquake and landslide hazards in the Tien Shan. From this study, we concluded first that a major hazard component is still now insufficiently known for both types of geohazards - and even totally unknown for most giant landslides: the time information. Thus, dating rockslides and any large mass movement is a crucial factor in order to better constrain related hazards. Second, we highlight the role of coupled hazards in the Tien Shan - inside the mountain range the largest disasters were caused by earthquake-triggered landslides and massive earth flows. Therefore, it is of prime importance for these mountain regions to complement single hazard assessment by coupled hazard scenarios. On the basis of these scenarios, risk evaluations may then be completed considering direct impacts on artificial dams, hydropower schemes, mining and road infrastructure as well as remote effects from possible dam breaches and mobilisation of mining and nuclear waste storages. Basic hazard and risk components are partly analysed in this paper and partly in a companion paper 'Tien Shan geohazards database: Landslide susceptibility and impacts'.
\end{abstract}

(C) 2015 Elsevier B.V. All rights reserved.

\section{Introduction}

Over the last decades a large number of studies have been focused on the seismo-tectonic context of the Tien Shan (see review in the next section); one of the major outcomes was the determination of the 'young' age of the Tien Shan (see next section), highlighting also the intense Neotectonic deformation within this mountain range;

\footnotetext{
* Corresponding author.

E-mail address: HB.Havenith@ulg.ac.be (H.B. Havenith).
}

earliest studies include the one by Schultz (1948) completed later by Makarov (1977) and Chedia (1986), more recent studies include those of Abdrakhmatov et al. (1996). Further, on the basis of the compiled seismo-tectonic information and a new seismic catalogue, Abdrakhmatov et al. (2003) computed the first probabilistic seismic hazard map for the Kyrgyz Tien Shan. They showed that parts of the Tien Shan (near the Southern and Northern borders) can be ranked among the most seismically hazardous regions of the world, characterized by Peak Ground Acceleration values of more than $0.5 \mathrm{~g}$ for a return period of 475 years. 
General landslide hazard analyses have a relatively long history in Central Asia. However, most of the earlier publications were in Russian (see, e.g., Fedorenko, 1988) and, thus, remained practically unknown in the Western World. Even more data have been stored in unpublished reports. Besides, due to state security requirements most of the figures in publications were presented without any geographic information, making them almost useless. A systematic location of larger landslides and of local landslide disasters was initiated by the Ministry of Emergency Situations of Kyrgyzstan (and possibly also of Tajikistan) in the 1990s. The catalogue updated to 2010 is part of our geohazards database, but it contains all locations as points, and not as full landslide outlines. Therefore, they were not taken into consideration for analyses of landslide statistics and susceptibility mapping (see companion paper Havenith et al., in this issue). Here, we present a new compiled landslide inventory (with outlines of landslide bodies as well as scarps for $40 \%$ of all mapped mass movements). It includes the one already published by Havenith et al. (2006a) and the one created by Schlögel et al. (2011) for the Maily-Say Valley.

During the last decade, a series of collaborative activities between the GeoForschungsZentrum Potsdam (Germany) and the Central Asian Institute of Applied Geosciences (Bishkek, Republic of Kyrgyzstan), partly involving also other institutes, have been focused on the reassessment of landslide and earthquake hazards all over the Tien Shan and neighbouring regions. In this regard, Haberland et al. (2011) announced the compilation of new seismic data and landslide information that should be used to assess related risk in the Fergana Basin, a subregion in the south-western Tien Shan. More recently, results of remote sensing and spatial analyses applied to landslide detection in some areas of the Tien Shan (mainly near the Fergana Valley) have been published by Behling et al. (2014) and Golovko et al. (2014).

With respect to previous publications and geohazards research activities in other regions of the world, we would like to highlight the special character of the present one - focusing both on landslide and earthquake hazards affecting almost the entire Tien Shan mountain range. The combined target of our data compilation for such a large area is due to the fact that the Tien Shan is particularly prone to earthquake-triggered landslides or to slope failures induced by combined seismic and climatic factors. Indeed, we assume that most large mapped mass movements (especially those with a volume of more than $10 \cdot 10^{6} \mathrm{~m}^{3}$ ) were triggered by major (generally prehistoric) earthquakes, possibly in combination with climatic factors (Havenith et al., 2003; Strom, 2010). Considering earthquake-triggered landslides at a world-wide scale, most data were published for major (single) earthquake events to understand the geomorphic impact of the latter and related induced (often called secondary) geohazards - a recent review on this topic has been published by Xu (2014). Prominent examples were presented by researchers from the USGS mainly for case histories from the USA, but also for some other regions of the world: the 1811-1812 New Madrid earthquakes, USA (Jibson and Keefer, 1989); the 1976 Guatemala earthquake (Harp et al., 1981); the 1989 Loma Prieta earthquake, USA (Griggs and Plant, 1998; Keefer and Manson, 1998); the 1991 Racha earthquake in Georgia (Borisoff and Rogozhin, 1992; Jibson et al., 1994); the 1994 Northridge Earthquake, USA (Harp and Jibson, 1995). The same was done in the study region after the major 1887 Vernyi earthquake (Mushketov, 1890), 1911 Kemin earthquake (Bogdanovich et al., 1914a; Delvaux et al., 2001), and the 1949 Khait earthquake (Gubin, 1960). Large databases were produced for recent major earthquakes affecting mountain ranges: see, e.g. Dadson et al. (2004) for the 1999 Chi-Chi earthquake in Taiwan (an earlier report was presented by Hung, 2000); Bommer et al. (2002) for the 2001 El Salvador Earthquake; Owen et al. (2008) for the 2005 Kashmir earthquake. For this $M=7.6$ earthquake in the Kashmir mountains in 2005 , Petley et al. (2006) estimated that about $30 \%$ of the total number of killed people $(26,500$ of the total death toll of 87,350$)$ had been victims of co-seismic landslides. The richest data set has probably been produced for the Mw = 7.9 2008 Wenchuan earthquake in Sichuan
Province, China, because this event had triggered an unprecedented number of landslides (>50,000, see, e.g. Gorum et al., 2011; and even about 200,000 landslides have been identified by Xu et al., 2014a). Coseismic landslides were estimated to have caused about 20,000 deaths, near one-third of the official estimate of 69,227 fatalities (Yin et al, 2009, with updated number of fatalities provided by Xu et al., 2014a). The 2010 Haiti earthquake also triggered several thousands of landslides (Gorum et al., 2013; according to Xu et al., 2014b, even more than 30,000 new landslides could be identified after earthquake); however, here it should be noted that landslides contributed relatively little to the total damage and extreme death toll related to the Haiti earthquake - first, because only a few large slope failures were triggered, and, second, most landslides affected thinly inhabited regions.

All these publications mainly focused on one single earthquake event. A first comparison between landslide distributions induced by different earthquakes (1999 Chi-Chi, 1989 Loma Prieta and 1994 Northridge), also considering respective triggering factors, was presented by Khazai and Sitar (2004). Finally, we would like to highlight the importance of compilations of socioeconomic aspects related to both earthquake-triggered and 'aseismic' landslides, such as the one published by Schuster and Highland (2001). Here, we will present only a few data on earthquake and landslide impacts in Central Asia, especially in the Tien Shan, as relatively little information is available.

\section{Tien Shan geohazards database: earthquakes}

Some particularities of the target 'geohazards' region, the Tien Shan, in Central Asia have already been outlined above: the relatively young age of the Tien Shan Orogeny (about 10 M years), the related strong seismo-tectonic activity and, importantly for our work, the close link between earthquake and landslide activity that can be established for large parts of the mountain range, especially along the Northern and Southern border zones. Morphological highlights of the Tien Shan are the steep rise at the Kyrgyzstan-China border (Tien Shan = 'Celestial Mountains' in Chinese), reaching a top altitude of $7453 \mathrm{~m}$ at the Peak of Victory. The probably most remarkable feature of this more than $2000 \mathrm{~km}$ long mountain range is the Issyk Kul Basin hosting one of the largest mountain lakes on Earth, the Eye of the Tien Shan (Fig. 1).

\subsection{Earthquake catalogue and Gutenberg-Richter Law}

The seismo-tectonic context of the Tien Shan is the core background information (together with morphological-hydrological factors, see companion paper Havenith et al., in this issue) needed to analyse geological hazards (with focus on landslides) affecting this large mountain range. Therefore, we will provide a more detailed introduction to this topic.

The present shape of the Tien Shan is considered to be the result of the post-collisional convergence of India with Asia (Molnar and Tapponnier, 1975; Allen et al., 1992), while its general geology is the result of a much longer tectonic activity. According to Khain (1977) and Allen et al. (1992), the collision accreting the Central Tien Shan, principally made of Palaeozoic granites, on the Precambrian Tarim block had started in Late Devonian-Early Carboniferous (see location of Tarim Basin in Fig. 1). The initial dextral strike slip movements along the Talas-Fergana Fault crossing the Tien Shan from SE to NW (Fig. 1) occurred in the Late Permian (Burtman et al., 1996). Cumulative displacements along this nearly $1000 \mathrm{~km}$ long fault amount to some $250 \mathrm{~km}$. To the south-east it is extended by the Karakorum fault in en-echelon manner with right step-over. The collision between India and Asia started in early Cenozoic times, about 50-55 Myr ago. Most of the Tien Shan was, however, constructed during the last 10 Myr. Abdrakhmatov et al. (1996) concluded this from modern GPS measurements revealing a mean shortening rate of $20 \mathrm{~mm} /$ year across the range. Thus, the deformation within the growing mountain belt was significantly delayed with regard to the onset of the collision. This deformation can be 


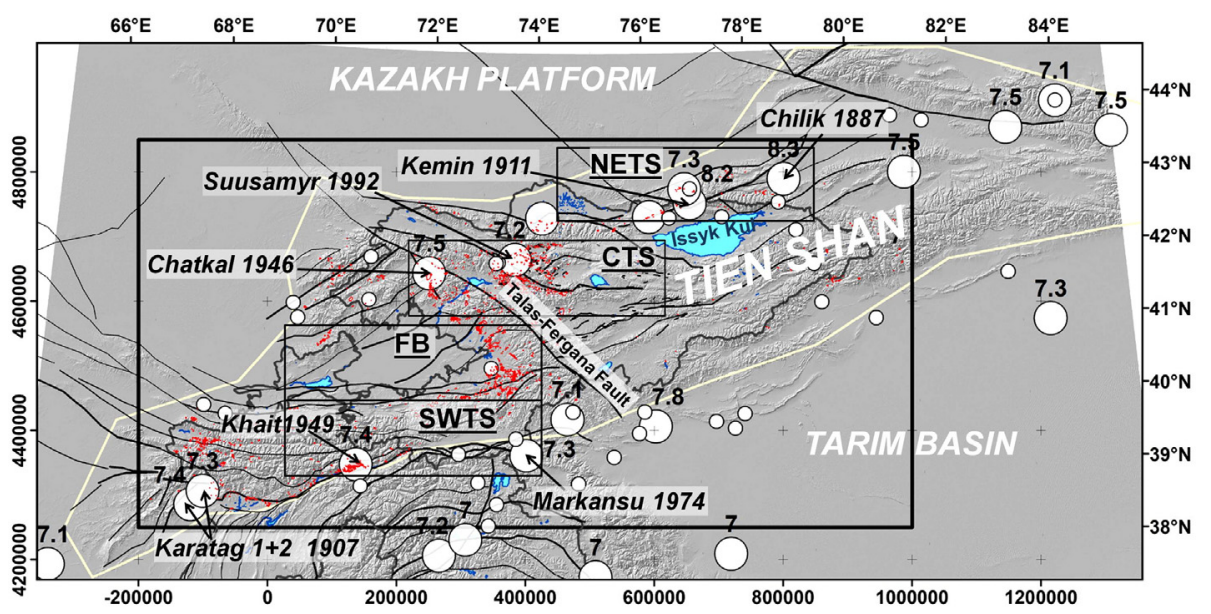

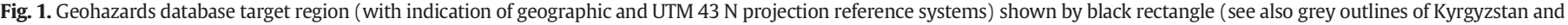

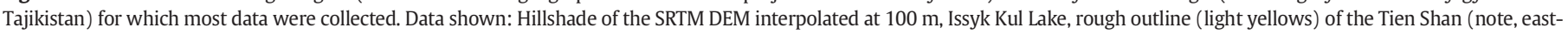

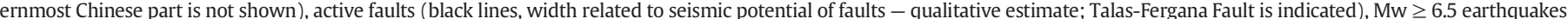

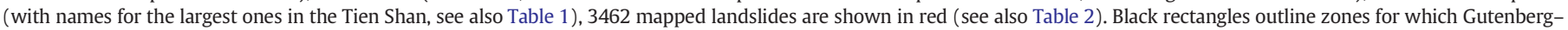
Richter Laws are presented in Fig. 2: the target region, NETS = North-East Tien Shan, CTS = Central Tien Shan, FB = Fergana Basin, SETS = South-East Tien Shan.

attributed to crustal thickening and strike-slip movements (Cobbold et al., 1993), but their relative importance is still open to question.

Seismo-tectonic consequences of the recent deformation inside the Tien Shan range are the presence of numerous faults scarps across the mountain range and the occurrence of large earthquakes. Some of the latter caused major disasters, but information for most of them is incomplete. According to the compiled data (Table 1 ), the $\mathrm{Mw}=7.4$ Khait earthquake, 1949, caused the largest disaster; however, considering the extreme uncertainty affecting the estimated casualty numbers, it could also be that the Karatag earthquakes 1 and 2 in 1907 (Northern Tajikistan, location in Fig. 1) or the Andizhan earthquake in 1902 (Fergana Basin, location in Fig. 3) produced more victims. Anyway, it seems that earthquakes caused more victims in Tajikistan than in Kyrgyzstan. Actually, the highest seismicity is observed all along the southern border of the Tien Shan (partly in Tajikistan, see Figs. 1 and 2 ). However, the largest historical earthquakes with magnitudes $\geq 8$ occurred near the northern border (but producing far fewer victims than the earthquakes along the southern border, see Table 1). The most recent $M>7$ earthquake was located in the Central Tien Shan, where, according to previous estimates, such large earthquakes could not be expected due to the lower seismicity of this part of the mountain range. Also, Abdrakhmatov et al. (2003) inferred from their statistical analyses that the $\mathrm{Mw}=7.2$ Suusamyr Earthquake, 1992, in the Central Tien Shan was an exceptional event for this zone (return period > 1000 years). Below, we present similar analyses, based on the concept of the Gutenberg-Richter Law (GRL), for this and three other subregions in the Tien Shan. These analyses are applied to the updated seismic catalogue (see events $M \geq 6.5$ in Fig. 1) compiled from the Central Asia Seismic Risk Initiative (CASRI) catalogue (Ms > 2.5, 2000 BC-12/ 2009, see Bindi et al., 2012) and the USGS catalogue (Ms > 3.7, 1/ 2010-5/2014). It should be pointed out, however, that most of the Tien Shan range was inhabited by nomads who had no written history

Table 1

Large earthquakes in the Tien-Shan. Loss estimates according to Kalmetieva et al. (2009), the CASRI catalogue (Bindi et al., 2012) and Bogdanovich et al. (1914a)

\begin{tabular}{|c|c|c|c|c|c|}
\hline Name & Time (day/month/year) & $\begin{array}{l}\text { Latitude } \\
\left({ }^{\circ} \mathrm{N}\right)\end{array}$ & $\begin{array}{l}\text { Longitude } \\
\left({ }^{\circ} \mathrm{E}\right)\end{array}$ & Mw & Number of fatalities and triggered landslides \\
\hline Aksu & 1716 & 43.20 & 81.00 & 7.5 & No data \\
\hline Belovodsk & $2 / 8 / 1885$ & 42.70 & 74.10 & 6.9 & $\begin{array}{l}54 \\
\text { Not confirmed: Bielogorka rock avalanche } 1\end{array}$ \\
\hline Vernyi & 08/06/1887 & 43.10 & 76.80 & 7.3 & $236-330$ \\
\hline Chilik & $11 / 07 / 1889$ & 43.20 & 78.70 & 8.3 & Not more than several tens \\
\hline Kashgar & $22 / 08 / 1902$ & 39.80 & 76.20 & 6.8 & No data \\
\hline Andizhan & $16 / 12 / 1902$ & 40.80 & 72.30 & 6.4 & 4722 \\
\hline Karatag $1+2$ & $21 / 10 / 1907$ & 38.50 & 67.90 & $\begin{array}{l}7.4 \\
7.3\end{array}$ & more than 1500 \\
\hline Kemin & 03/01/1911 & 42.90 & 76.90 & 8.2 & $\begin{array}{l}452 \\
\text { Kaindy rockslide killed } 38 \text { inhabitants of yourt } \\
\text { village, Ananevo rockslide } \\
\text { and rockslide in present-day Kazakhstan }\end{array}$ \\
\hline Kemin-Chuy & 20/06/1938 & 42.70 & 75.80 & 6.9 & No data \\
\hline Chatkal & 02/11/1946 & 41.90 & 72.00 & 7.5 & No data \\
\hline Khait & $10 / 07 / 1949$ & 39.20 & 70.80 & 7.4 & $\begin{array}{l}>20,000 \\
\text { Likely }>50 \% \text { killed by landslides }\end{array}$ \\
\hline Markansu & $11 / 08 / 1974$ & 39.23 & 73.83 & 7.3 & No data \\
\hline Jalanash-Tiup & 24/03/1978 & 42.87 & 78.58 & 7 & No data \\
\hline Suusamyr & 19/08/1992 & 42.07 & 73.63 & 7.5 & $\begin{array}{l}>50 \\
\text { Likely more than } 30 \text {, including postseismic debris flow }\end{array}$ \\
\hline Gissar & 23/01/1989 & 38.465 & 68.69 & 5.5 & $\begin{array}{l}274 \\
\text { Mainly killed by loess flows }\end{array}$ \\
\hline Nura & 05/10/2008 & 39.62 & 73.67 & 6.6 & 74 \\
\hline
\end{tabular}




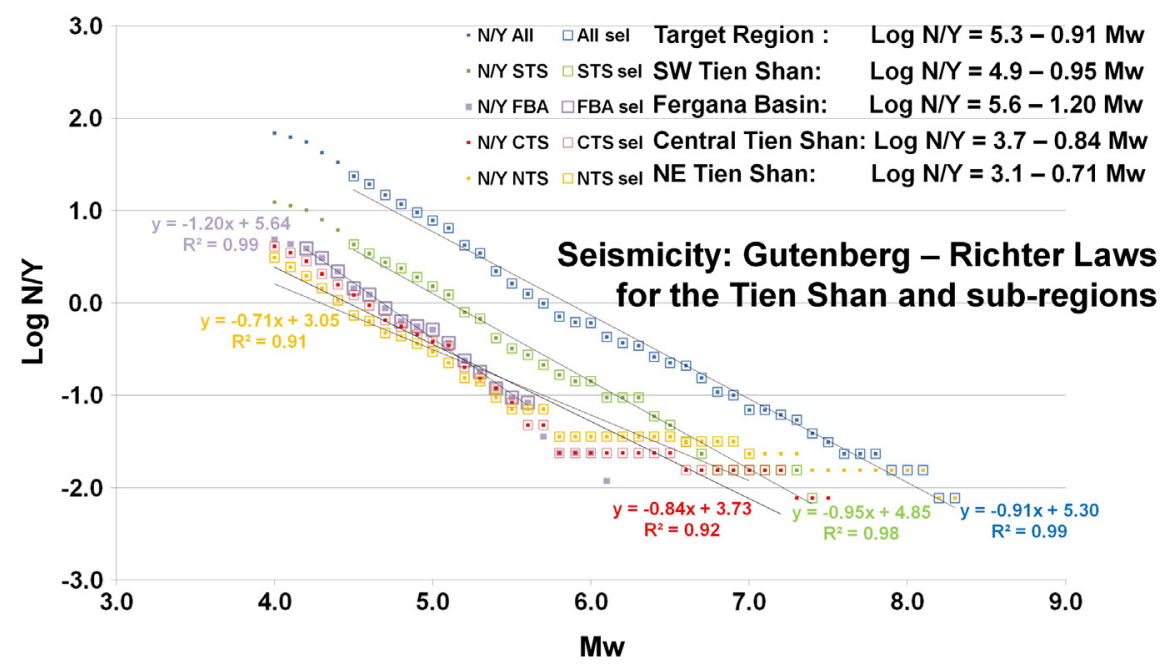

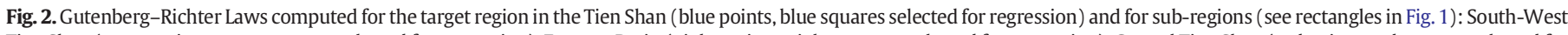

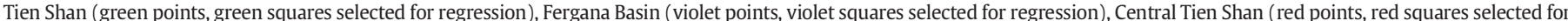

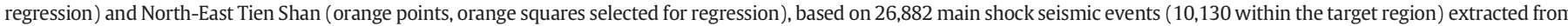
the combined CASRI (250 BC-2009 AD) and USGS earthquake catalogues (2010-2013) containing 34,354 data (all magnitudes have been transformed into moment magnitude Mw)

in the past and, thus, the representative earthquake catalogue does not extend over more than 200-300 years before present. For the statistics presented below (Fig. 2), we considered only events of the last 130 years (starting from 1885 when more detailed information was collected as a consequence of the $\mathrm{Mw}=6.9$ Belovodsk earthquake that strongly hit the area around Pishpek, present-day Bishkek, in 1885). The compiled catalogue contains 34,354 events for an area Lat $33.7^{\circ}-$ $61.4^{\circ} \mathrm{N}$, Lon $47.0^{\circ}-90.0^{\circ} \mathrm{E}$ (covering most of Central Asia, including the Altai, Pamir, northern mountain ranges of Persia in the East of the Caspian Sea, the Hindu Kush, Kashmir and Karakorum).

On the basis of the seismic catalogue updated in 2001, Abdrakhmatov et al. (2003) presented the first size-frequency relationships of earthquakes for 24 seismic zones in the Kyrgyz Tien Shan (and surrounding areas) in the form of GRL of type:

$\log (N)=a-b M$

where $N$ is the number of earthquakes per year larger than a certain magnitude $M, a$ is the number of earthquakes per year larger than $\mathrm{M}=0$ and $b$ is the decay value. It should be noticed that for the GRL only main-shock events have to be considered as the concept is based on the independency of each event. Aftershocks (and the generally less frequent foreshocks) by definition are related to a main shock and thus depend on it. Therefore, the catalogue has first to be 'cleaned' from after- and foreshocks.

Abdrakhmatov et al. (2003) showed that the G-R Law for the entire Kyrgyz Tien Shan (and surrounding areas) is the following:

$\log (N)=5.25-0.9 M s$

using the surface wave magnitude Ms as magnitude scale, the a-value is 5.25 , and the b-value is 0.9 .

For the 24 seismic zones in the Tien Shan, Abdrakhmatov et al. (2003) determined a-values ranging from 2.1 to 4.6, and b-values ranging from 0.7 to 1.3 . On one hand, a-value represents somehow the number of earthquakes in one region and, thus, also depends on the size of it; however, for zones with similar size, larger a-values characterize areas with higher seismicity. Thus, it is not surprising that the highest avalues were obtained for zones along the southern border of the Tien Shan. On the other hand, the b-value reflects the weight of large earthquakes compared to small earthquakes in one region. Low b-values indicate a relatively higher weight of large earthquakes compared to the smaller ones. Abdrakhmatov et al. (2003) obtained the smallest bvalues (below the regional value of 0.9) for zones in the Northern and Central Tien Shan, thus marked by the relatively strongest weight of large earthquakes. The highest b-values were obtained for basin areas, mainly the Issyk Kul Basin and the Fergana Basin where no $M>7$ events have ever been recorded.

Below, we present Gutenberg-Richter Laws for rectangular zones located in those different parts of the Tien Shan to highlight the strong changes of seismicity. Therefore, as announced above, all fore- and aftershocks were removed from the entire new catalogue: out of the total 34,354 events, 26,882 have been defined as main shock events. Within the target region (bold black rectangle in Fig. 1), 10,130 of such main shock events with $M \geq 4$ were used for the analyses. Fig. 2 shows that this entire target region has an a-value of 5.3 and a b-value of 0.91 (see blue points and related regression line). The slightly higher a-value is mainly due to the fact that the target region here is a bit larger than the one defined by Abdrakhmatov et al. (2003) who included only a very small part of northern Tajikistan in their study area. For the south-western Tien Shan (green points and related regression line in Fig. 2), we obtain both larger a- and b-values than Abdrakhmatov et al. (2003), respectively, 4.9 versus 4.6 and 0.95 versus 0.87 . Both changes are actually connected to each other: a larger b-value entrains a larger a-value as the number of small earthquakes (including those of $\mathrm{M}=0$ used for calculation of the a-value). This higher b-value is mainly due to a larger number of $\mathrm{M}<6$ earthquakes recorded over the past 12 years (compared to the period before 2002). For the Fergana Basin (violet points and related regression line in Fig. 2), very high aand b-values of respectively 5.6 and 1.2 were obtained (compared to the b-value of 1.0 determined by Abdrakhmatov et al., 2003). Here, the same trend can be observed as for the SW Tien Shan: these higher a- and b-values are due to a relative increase of small earthquakes compared to larger ones recorded over the past 12 years. Finally, for the central and north-eastern Tien Shan, the expected relatively lower a- (3.7 and 3.1) and b-values (0.84 and 0.71) were obtained that can be compared with those of Abdrakhmatov et al. (2003), considering the changed size of the zones. For these zones, it seems that number of small earthquakes did not increase compared to the period before 2002 .

The analysis of the seismic catalogue and the determination of the seismicity of different zones in terms of a- and b-values (of the G$\mathrm{R}$ Law) is the basic task of the seismic hazard computation. It can be used to assess the return periods of major earthquakes for the entire area or within sub-regions. Thus, according to the defined GRL, 
a magnitude 7 earthquake (or larger) occurs once every 10 to 20 years in the entire target region (note, the last occurred already more than 20 years ago in 1992), while the return periods for such an earthquake are 90 to 100 years in the SW and NE Tien Shan, 200 years in the central Tien Shan and almost 1000 years in the Fergana Basin. The next steps are the determination of an attenuation law (calculation of acceleration values for rock sites at varying distances from earthquake epi- or hypocentres) and the computation of probabilities of exceedance of a certain acceleration or intensity value for each site within the considered region. Developing the full sequence of seismic zonation, attenuation law definition and probabilistic analysis is not the goal of this paper; here, we present G-R Laws for some regions, mainly to compare them with landslide size-frequency analyses presented in Section 4. In the Discussion section, we will also compare the spatially changing type of seismicity with the distribution of larger mass movements. Both, the size-frequency and the spatial analysis of mass movements are based on a new landslide inventory.

\section{Tien Shan geohazards database: landslides}

The landslide inventory was compiled from various digital maps of rockslides produced by the authors (see, e.g., Strom and Korup, 2006, for a description of the largest identified rockslides) as well as landslide maps created in the frame of Master's Theses completed at the University of Liege, Belgium (Schlögel, 2009; Dupont, 2011; Burette, 2012). Additionally, more than 1800 other landslides have been mapped recently in soft sediments (around the Fergana Basin and along the southern border of the Tien Shan, see landslides outlined in yellow near the zones Z3, Z4, Z5 in Fig. 3) and also in rocks (see, e.g., Zeravshan range - Z2 in Fig. 3) to complete a coherent landslide inventory for most parts of the Tien Shan (excluding the easternmost part representing $30 \%$ of the entire range where only the largest mass movements have been mapped, see also Strom, 2010).

The basic layer of the Geohazards database is the SRTM $90 \mathrm{~m}$ Digital Elevation Model (DEM) that was re-sampled and interpolated at a resolution of $100 \mathrm{~m}$. All other Raster-Image data were produced at the same $100 \mathrm{~m}$ resolution. Initially no specific extent was used, but when all data were overlaid, the following extent was defined (including also all landslide data) for the production of raster information (projection of UTM 43 N, false easting 500,000): W-E -200,000-
$1,000,000$; S-N 4,250,000-4,850,000; thus, the target area covers $1200 \times 600 \mathrm{~km}=720 \cdot 10^{3} \mathrm{~km}^{2}$

\subsection{Data and methods used for landslide mapping}

Landslides were mainly digitized (manually) from Google ${ }^{\circledR}$ Earth imagery; the outlines were then reformatted as shapefile (polygon entities) for use on a common GIS platform (here, $\operatorname{ArcGIS}^{\odot} 10.2$ ). This mapping had been completed only recently since for many areas highresolution imagery was not available in Google ${ }^{\mathbb{\Theta}}$ Earth before 2012. Even now, some remote high mountain regions are only covered by the relatively low-resolution LANDSAT imagery. Most of these areas (representing $10 \%$ of the entire target region, located mostly above $3000 \mathrm{~m}$ altitude) were generally excluded from mapping (about 10 large landslides had been identified in those areas).

For at least 100 landslides in hard and soft rocks, field observations have been collected over more than 15 years. For those, photographic material is available. Notably, in the central Tien Shan, field surveys are carried out by students in the frame of a field school organised by Strom and Abdrakhmatov (2009). Geophysical field surveys have been completed on/near a dozen of mainly earthquake-triggered mass movements; related results were presented in Master's Theses (de Marneffe, 2010; Dupont, 2011; Deprez, 2012); earlier surveys are summarized by Havenith et al. (2003, 2006a), Danneels et al. (2008). For sub-regions, such as the Maily-Say Valley (part of Z4 in Fig. 3) also high-resolution imagery (panchromatic and multi-spectral Quickbird) had been used to map landslides (see Schlögel et al., 2011). First mapping of landslides (before 2006) was also completed with Aster, SPOT, Corona and KFA1000 imagery. Also automatic detection methods were applied to multi-spectral imagery in order to identify landslides in smaller subregions (see Danneels et al., 2007; Schlögel et al., 2011).

As indicated above, the landslide inventory was created for a target zone area of $1200 \times 600 \mathrm{~km}$. Large rockslides were also mapped outside this area, especially in the eastern Chinese Tien Shan. These data are not presented here (some examples are shown in Strom, 2010). Inside the target area, 3462 landslides were mapped. Within the countries of Kyrgyzstan and Tajikistan, for which geographic, geological and climatic information were compiled, 1807 landslides are located in soft rockssediments and 1389 landslides in hard rock (the basic geological layer used for this distinction is presented in the companion paper Havenith et al., in this issue). In addition, 26 earth flows triggered by the 1949

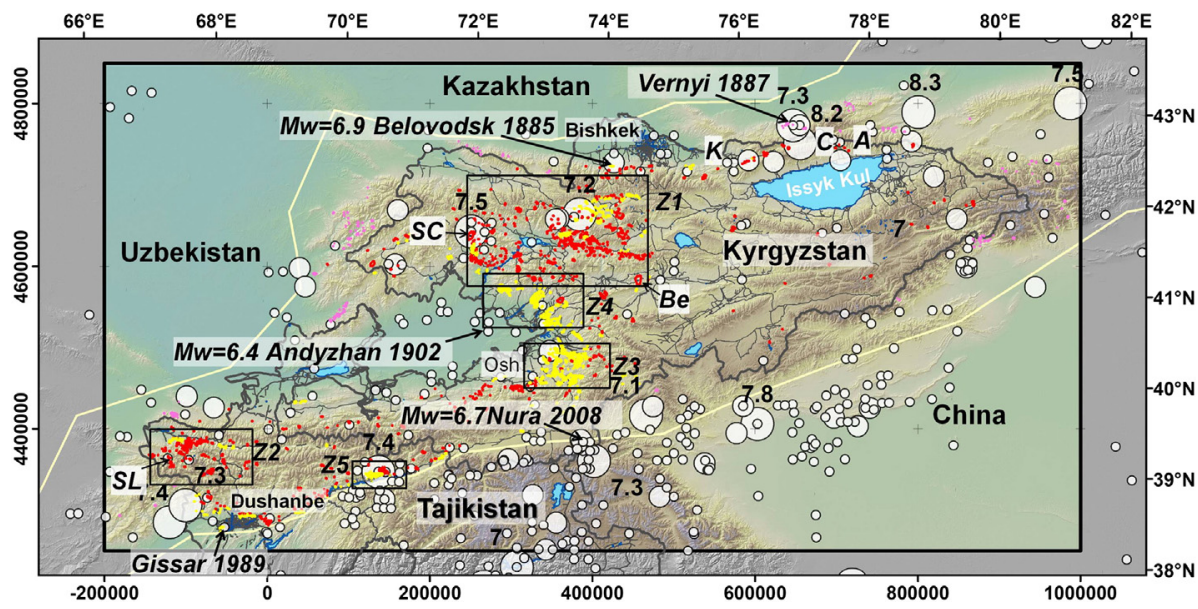

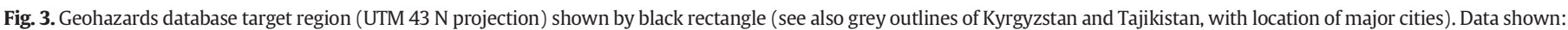

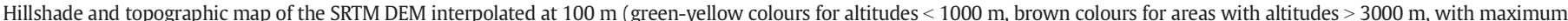

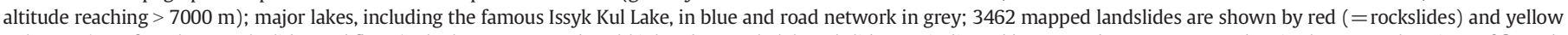

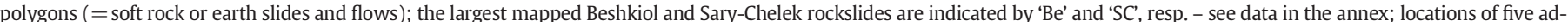

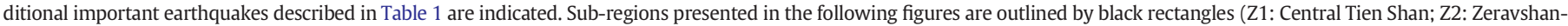

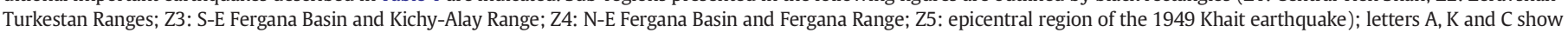
location of the Ananevo, Kaindy rockslides and Chon-Aksu fault scarp sites shown in Fig. 8. 
Khait earthquake (see Fig. 9 and paragraph 3d), were digitized from a map prepared by Gubin in 1949 (Gubin, 1960) and reproduced in Evans et al. (2009) - most of them could not be identified from recent imagery and therefore were not used for statistical analyses presented below. Finally, 240 landslides were mapped outside Kyrgyzstan and Tajikistan (in Uzbekistan, Kazakhstan and China). It is important to note that each polygon outlines the entire mass movement, including the landslide scarp and body. Scarps have been outline for about 1500 of the mapped landslides. These additional features were used for the landslide susceptibility analyses presented in a companion paper by Havenith et al. (in this issue). All landslide outlines besides those of the earth flows triggered by the Khait event were considered for sizefrequency analyses (see Section 4).

In the following, the seismo-tectonic and morphological context of the mapped mass movements will be exemplified on the basis of a series of zones (Z1-Z5 outlined in Fig. 3) that include particularly large rockslides, areas of high landslide concentration, landslide disaster case histories partly related to earthquake-triggered landslides. In most of these zones, the authors of this paper have been conducting extensive field surveys over the last 20-35 years. As most information was collected for these areas, we acknowledge that part of the higher landslide density in the highlighted zones may be related to the enhanced availability of data. However, a series of areas not included in the rectangles Z1-Z5 had been visited as well and found clearly less susceptible to landsliding either because the local relief is less pronounced or due to higher slope stability in high-mountain permafrost regions; these aspects will be discussed below.

Some information about recent landslide disasters (after 1990) is presented in Table 2. This table does not reflect the total impacts of landslides in Kyrgyzstan, but gives only a small overview of some recent disasters related to landslide activation. None of these mass movements would be considered 'large' (according to the definition above, $>10 \cdot 10^{6} \mathrm{~m}^{3}$ ) and none was directly caused by an earthquake - the main trigger of such relatively frequent smaller landslides is intense and long-lasting precipitation. However, it will be shown that at least for some of these mass movements (e.g., the Kainama landslide in 2005) medium-size local earthquakes $(M>4.5$, within a distance of $50 \mathrm{~km}$ ) may have acted as pre-trigger, as they occurred a few weeks before the landslide.

\subsection{Landslide types: giant landslides and natural dams}

This section is partly based on the data already published by Strom (2010) 'Landslide dams in Central Asian regions' - as most giant landslides form or formed dams on rivers. 'Giant' is certainly a relative notion to qualify the size of a mass movement. Here, we use it for landslides with an estimated volume of more than $10^{7} \mathrm{~m}^{3}$ (see also definition of 'large' above). The largest landslide forming a dam at present time within the target area is likely to be the Sary-Chelek rockslide in the western Tien Shan (within Z1 in Fig. 3). It has an estimated volume of 5-6 $\mathrm{km}^{3}$ (and may be even more than $6 \mathrm{~km}^{3}$ according to Strom and Korup, 2006). This volume is only exceeded by the already breached rockslide dam of Beshkiol rockslide located in the south-east of zone
Z1. This zone Z1 has been studied in detail by Strom (2012), and was also the target of a series of geophysical surveys over the last 16 years (see, e.g., Havenith et al., 2000; Torgoev et al., 2013). Actually, within this zone, several points of interest can be highlighted: first, this area was the last to be hit by a $M>7$ earthquake, the 1992 Suusamyr earthquake, that triggered the Belaldy rock avalanche- this one formed a dam with an initial volume of $40 \cdot 10^{6} \mathrm{~m}^{3}$, but which was reduced after dam breach in 1993 (an extensive description of this rock avalanche can be found in Havenith and Bourdeau, 2010; see also Table 3); second, a generally higher concentration of rock slope failures (including giant mass movements) can be observed in this area, compared to other internal mountain regions of the Tien Shan; third, it is crossed by the Suusamyr, Kekemeren and Naryn rivers on which more than a dozen rockslide dams had been formed in the past; fourth, it is crossed by the TalasFergana Fault (located in Fig. 1) and the associated valley hosting large rock avalanches damming the Kara Suu and Kapka Tash Lakes (Strom, 2010); fifth, it includes several hydraulic schemes and the Minkush mining region with the presence of several nuclear waste tailings, some of which might be impacted directly or indirectly (through flooding) by landslides (see Section 5).

Strom (2010) provides valuable information on the ages of such ancient giant rockslides. For instance, he presents data indicating that the aforementioned Kara Suu rock avalanche would have a minimum age of 3 ka or slightly less.

Some clusters of recent landslides and ancient rockslides possibly formed during large earthquakes can be found in the Western part of the Zeravshan-Turkestan ranges, such as a series of rock avalanches (with volumes of about $1 \times 10^{6}$ up to $>100 \times 10^{6} \mathrm{~m}^{3}$ ) in the south of Panjakent damming the 'Seven Lakes' (see Fig. 4a).

With these examples we would also like to address a major uncertainty connected with landslide mapping in higher mountain regions: it is often not possible to clearly distinguish between rockslide and moraine deposits. In these cases, field investigations would be needed to remove this uncertainty (e.g. rockslide deposits are mainly composed of angular blocks and moraine deposits of rounded blocks). In the case of the 'Seven Lakes' dams, it could be that the two upper dams located above $2000 \mathrm{~m}$ are partly or entirely composed of moraine material. The same uncertainty exists for the Iskander Kul Lake (see 'IK' in the map in Fig. 4) that could be dammed either by rockslide or by moraine deposits (or both). As we found clear scarps above the deposits, we consider them as a result of 'rocksliding', but we do not exclude that the scarp could also have another origin.

The Zeravshan range also hosted a major relatively recent important mass movement event. Near the town of Aini, a $20 \times 10^{6} \mathrm{~m}^{3}$ rockslide occurred on April 24, 1964, and dammed Zeravshan River (with an effective height of 50-60 m, see Fig. $4 \mathrm{~b}$ ). The storage potential behind this dam was estimated at up to $126 \times 10^{6} \mathrm{~m}^{3}$. In order to prevent a major lake outbreak disaster, an $865 \mathrm{~m}$ long and $23 \mathrm{~m}$ deep trench had been excavated by directed blasts. After two weeks, water flow started through this channel with a peak discharge of $1200 \mathrm{~m}^{3} / \mathrm{s}$ reached at the end of May 1964. As related flooding did not cause any serious damage, this case study is considered as one of the first successful preventions of rockslide dam breach disaster (Strom, 2010). The

Table 2

The deadliest single landslides in Kyrgyzstan, starting from 1990 (Kalmetieva et al., 2009; Ministry of Emergency Situations, Kyrgyz Republic).

\begin{tabular}{|c|c|c|c|c|c|c|}
\hline Name/Position & Time $(\mathrm{d} / \mathrm{m} / \mathrm{y})$ & Volume, $\left(\mathrm{m}^{3}\right)$ & Victims & $\begin{array}{l}\text { Latitude } \\
(\mathrm{N})\end{array}$ & $\begin{array}{l}\text { Longitude } \\
\text { (E) }\end{array}$ & $\mathrm{H}(\mathrm{m})$ \\
\hline Mailuu-Suu, Left slope of Bedre-Sai & 21/03/1994 & 100000 & 8 & $41^{\circ} 15^{\prime} 9.05^{\prime \prime}$ & $72^{\circ} 26^{\prime} 45.37^{\prime \prime}$ & 1009 \\
\hline Komsomol village, Uzgen area/Kyrgyzstan & 26/03/1994 & 500,000 & 28 & $40^{\circ} 43^{\prime} 28.85^{\prime \prime}$ & $73^{\circ} 31^{\prime} 14.81^{\prime \prime}$ & 1319 \\
\hline Tosoy village, Uzgen area/Kyrgyzstan & 08/08/1994 & $1,000,000$ & 50 & $40^{\circ} 57^{\prime} 1.73^{\prime \prime}$ & $73^{\circ} 29^{\prime} 20.89^{\prime \prime}$ & 1593 \\
\hline Raikomol village, Aksy region/Kyrgyzstan & May 1995 & 40000 & 4 & $41^{\circ} 36^{\prime} 16.84^{\prime \prime}$ & $72^{\circ} 14^{\prime} 45.15^{\prime \prime}$ & 1060 \\
\hline Kara-Taryk village, Uzgen area/Kyrgyzstan & $20 / 04 / 2003$ & $1,500,000$ & 38 & $40^{\circ} 37^{\prime} 21.85^{\prime \prime}$ & $73^{\circ} 17^{\prime} 41.35^{\prime \prime}$ & 1572 \\
\hline Mailuu-Suu, Right slope of Bedre-Sai & March 2004 & 50000 & 2 & $41^{\circ} 15^{\prime} 20.38^{\prime \prime}$ & $72^{\circ} 26^{\prime} 21.38^{\prime \prime}$ & 1018 \\
\hline Kainama village, Alay region/Kyrgyzstan & $24 / 04 / 2004$ & $2,000,000$ & 33 & $40^{\circ} 16^{\prime} 20.77^{\prime \prime}$ & $73^{\circ} 33^{\prime} 50.72^{\prime \prime}$ & 1872 \\
\hline Raikomol village, Aksy region/Kyrgyzstan & $15 / 04 / 2009$ & 200,000 & 16 & $41^{\circ} 35^{\prime} 52.67^{\prime \prime}$ & $72^{\circ} 14^{\prime} 18.43^{\prime \prime}$ & 1033 \\
\hline
\end{tabular}


Table 3

Landslide surface area, thickness and volume.

\begin{tabular}{|c|c|c|c|c|c|c|c|c|c|}
\hline \multirow[t]{2}{*}{ Numb. } & \multirow[t]{2}{*}{ Landslide } & \multirow[t]{2}{*}{ Coordin. } & \multirow{2}{*}{$\frac{\text { Shown }}{\text { in }}$} & \multirow{2}{*}{$\frac{\text { Area }}{\left(10^{3} \mathrm{~m}^{2}\right)}$} & \multirow{2}{*}{$\begin{array}{l}\text { Calc. max. } \\
\text { thickn. } \\
(\mathrm{m})\end{array}$} & \multirow{2}{*}{$\begin{array}{l}\text { Prev. vol. } \\
\text { estim. } \\
\left(10^{6} \mathrm{~m}^{3}\right)\end{array}$} & \multirow[t]{2}{*}{ Reference } & \multirow{2}{*}{$\frac{\text { Calc. vol. }}{\left(10^{6} \mathrm{~m}^{3}\right)}$} & \multirow[t]{2}{*}{ Agreement } \\
\hline & & & & & & & & & \\
\hline V01 & Suusamyr landslide, C. Tien Shan & $42.207^{\circ} \mathrm{N}, 73.610^{\circ} \mathrm{E}$ & See ref. & 126.90 & 20.1 & 0.75 & Havenith et al. (2003) & 0.85 & Accept. \\
\hline V02 & Okuli loess flow, Gissar & $38.480^{\circ} \mathrm{N}, 68.620^{\circ} \mathrm{E}$ & Fig. 8a & 2027.00 & 45.3 & 20.00 & Ishihara et al. (1990) & 30.60 & Overest. \\
\hline V03 & Kainama loess flow, Alay & $40.275^{\circ} \mathrm{N}, 73.565^{\circ} \mathrm{E}$ & See ref. & 151.30 & 13.9 & 0.40 & Danneels et al. (2008) & 0.70 & Overest. \\
\hline V04 & Koytash landslide, Maily Say & $41.290^{\circ} \mathrm{N}, 72.480^{\circ} \mathrm{E}$ & See ref. & 277.80 & 30.6 & 3.00 & Authors prev. estimate & 2.83 & Accept. \\
\hline V05 & Tektonik landslide, Maily Say & $41.285^{\circ} \mathrm{N}, 72.480^{\circ} \mathrm{E}$ & See ref. & 326.00 & 18.1 & 2.00 & Authors prev. estimate & 1.97 & Accept. \\
\hline V06 & Kochkor Ata loess flow, Maily Say & $41.260^{\circ} \mathrm{N}, 72.555^{\circ} \mathrm{E}$ & Fig. 6a, b & 968.50 & 20.0 & 10.00 & Roessner et al. (2005) & 6.46 & Underest. \\
\hline V07 & Isolith landslide, Maily Say & $41.280^{\circ} \mathrm{N}, 72.470^{\circ} \mathrm{E}$ & See ref. & 112.90 & 20.6 & 0.60 & Authors prev. estimate & 0.78 & Accept. \\
\hline V08 & Yasman loess flow & $39.175^{\circ} \mathrm{N}, 70.750^{\circ} \mathrm{E}$ & Fig. 7a, b & $33,143.10$ & 21.3 & 245.00 & Evans et al. (2009) & 235.22 & Accept. \\
\hline V09 & Bielogorka Rock avalanche 1, N Tien Shan & $42.635^{\circ} \mathrm{N}, 74.280^{\circ} \mathrm{E}$ & See ref. & 1075.60 & 48.4 & 20.00 & Havenith et al. (2003) & 17.35 & Accept. \\
\hline V10 & Bielogorka Rock avalanche 2, N Tien Shan & $42.640^{\circ} \mathrm{N}, 74.290^{\circ} \mathrm{E}$ & See ref. & 863.80 & 38.9 & 10.00 & Havenith et al., (2003) & 11.19 & Accept. \\
\hline V11 & Ananevo rockslide, NE Tien Shan & $42.805^{\circ} \mathrm{N}, 77.630^{\circ} \mathrm{E}$ & Fig. 8d & 720.80 & 76.5 & 15.00 & Havenith et al. (2003) & 18.38 & Accept. \\
\hline V12 & Kemin rockslide, NE Tien Shan & $42.720^{\circ} \mathrm{N}, 76.205^{\circ} \mathrm{E}$ & Fig. 8e & 750.10 & 68.8 & 15.00 & Authors prev. estimate & 17.21 & Accept. \\
\hline V13 & Kara Suu rock avalanche, C. Tien Shan & $41.570^{\circ} \mathrm{N}, 73.220^{\circ} \mathrm{E}$ & See ref. & 3735.50 & 106.0 & 280.00 & Strom (2010) & 132.00 & Underest. \\
\hline V14 & Karakol rockslide & $41.650^{\circ} \mathrm{N}, 72.660^{\circ} \mathrm{E}$ & See ref. & 2786.70 & 126.5 & 300.00 & Strom (2010) & 110.00 & Underest. \\
\hline V15 & Belaldy rock avalanche (partial dam) & $42.060^{\circ} \mathrm{N}, 73.280^{\circ} \mathrm{E}$ & See ref. & 906.10 & 62.5 & 40.00 & Korjenkov et al. (2004) & 18.87 & Underest. \\
\hline V16 & Sary-Chelek rockslide, west. Tien Shan & $41.850^{\circ} \mathrm{N}, 72.000^{\circ} \mathrm{E}$ & See ref. & $43,567.10$ & 531.0 & 6000.00 & Strom $(2010)$ & 7711.28 & Accept. \\
\hline V17 & Beshkiol rockslide, central Tien Shan & $41.400^{\circ} \mathrm{N}, 74.480^{\circ} \mathrm{E}$ & See ref. & $56,059.40$ & 588.6 & $10,000.00$ & Strom (2010) & $10,998.66$ & Accept. \\
\hline V18 & Khait rock avalanche, S Tien Shan & $39.185^{\circ} \mathrm{N}, 70.880^{\circ} \mathrm{E}$ & Fig. 7c & 5747.60 & 41.5 & 75.00 & Evans et al. (2009) & 79.57 & Accept. \\
\hline V19 & Iskander Kul rockslide, SW Tien Shan & $39.080^{\circ} \mathrm{N}, 68.420^{\circ} \mathrm{E}$ & Fig. 4 & $17,063.80$ & 196.5 & 1000.00 & Strom (2010) & 1117.95 & Accept. \\
\hline V20 & Aini rockslide dam (remaining part) & $39.380^{\circ} \mathrm{N}, 68.540^{\circ} \mathrm{E}$ & Fig. 4b & 592.40 & 36.5 & 20.00 & Strom (2010) & 7.21 & Underest. \\
\hline
\end{tabular}

Comments on volume estimates with no agreement.

V02 Okuli: calculated volume probably overestimated - formula less effective for loess flows.

V03 Kainama: calculated volume probably overestimated - formula less effective for loess flows.

V06 Kochkor Ata: previous estimate probably too high (authors estimate that the volume is about 5-6 $10^{6} \mathrm{~m}^{3}$ ).

V13 Kara Suu: previous estimate probably too high - or considering other outline of rockslide.

V14 Karakol: previous estimate probably too high - or considering other outline of rockslide.

V15 Belaldy: volume estimate of $4010^{6} \mathrm{~m}^{3}$ was before dam breach - the volume was reduced after debris flow (probably by several million $\mathrm{m}^{3}$ ).

V20 Aini: volume estimate of $2010^{6} \mathrm{~m}^{3}$ was before dam breach - the volume was reduced after breach (how much?).

Note: data on the landslides in the Maily-Say region are presented in the companion paper Havenith et al. (in this issue).

dam was partly eroded and now about $50 \%$ of the dam volume is left (Table 3).

\subsection{Landslide types: loess landslides}

Giant rockslides as those introduced above occur over highly variable time intervals (often more than several tens of years), while another particular type of mass movement is much more common: small and medium-sized loess landslides.

The loess landslides occur quite regularly (on a yearly basis) in the regions presenting an almost continuous and locally very thick $(>20 \mathrm{~m}$ ) cover of this material, generally at mid-mountain altitude (900-2300 m) and mainly along the border of the Fergana Basin (Kyrgyzstan, Uzbekistan and Tajikistan) and the southern border of
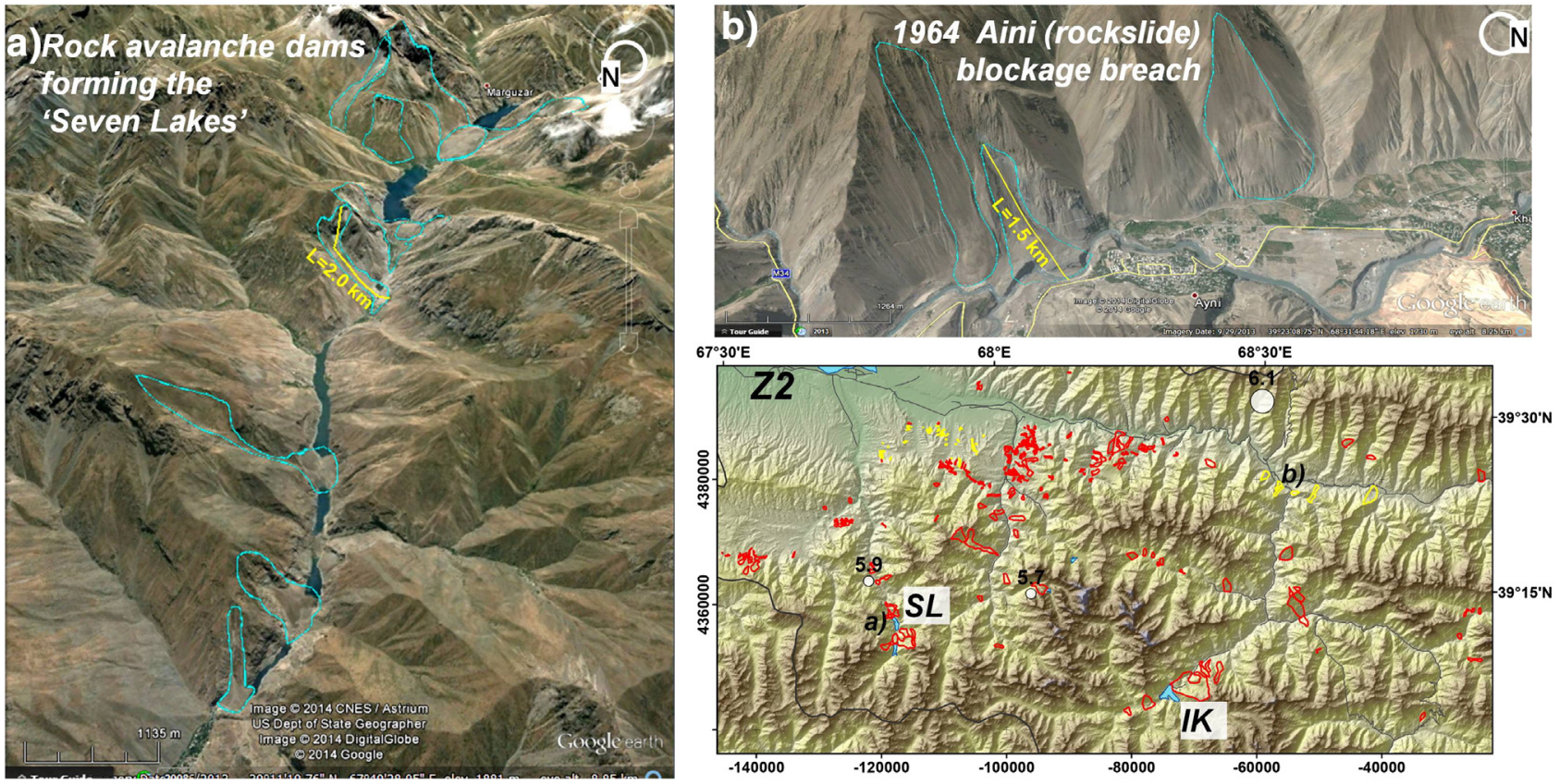

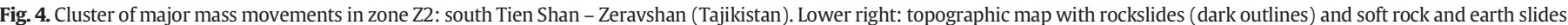

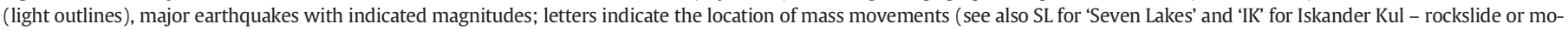

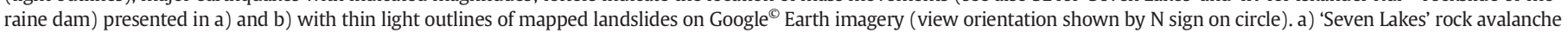
dams (see section length of $2.0 \mathrm{~km}$ ); (b) breached Aini rockslide dam (event in 1964, with initial dam volume of $20 \times 10^{6} \mathrm{~m}^{3}$ ). 
the Tien Shan in Tajikistan (but some other areas are also known along the northern Tien Shan). Most of these landslides are related to rainfall and snow melt in the spring period. During years with intensified climatic conditions, some massive activations can be observed such as in Kyrgyzstan in 1994, 2003, 2004 and 2009 (see also Table 2).

In Fig. 5 we present some views of clusters of loess landslides and mixed loess - soft rock landslides in zone Z3, the SE Fergana-Kichy Alay region. Typically, pure loess landslides have a volume of hundreds up to one million cubic metres and appear as clusters (see Fig. 5). However, if failure also affects underlying materials (mostly Mesozoic and Cenozoic soft rocks), the volume of these mixed slides can exceed $10 \times 10^{6} \mathrm{~m}^{3}$ (see slide with section of $2.5 \mathrm{~km}$ in Fig. $5 \mathrm{a}-$ with an estimated volume of more than $50 \times 10^{6} \mathrm{~m}^{3}$ ). In 2002 , such a mixed loess - soft rock landslide affected parts of the town of Gulcha in the Kichy Alay Mountains (Fig. 5b).

In the same region, one year later, in 2003, a pure loess landslide killed 38 people in the village of Kara Taryk and, in 2004, another pure loess landslide killed 33 people in the village of Kainama (see location of both sites in the map in Fig. 5).

The Kainama landslide had been visited directly after the disaster and investigated in summer 2005. On the basis of these investigations and modelling of possible trigger factors, Danneels et al. (2008) concluded that this loess flow was most likely due to a combination of long-term slope destabilisation and short-term triggers. The latter include intensified water infiltration in ground fractures that may have appeared after two Ms $=4.4$ and $\mathrm{Ms}=4.5$ events that occurred 2 weeks before the landslide (on April 8 and 9, 2004, at an epicentral distance of 43 and $45 \mathrm{~km}$, respectively). From the recent history we know that especially the pure (or quasi pure) loess slides and flows cause more severe disasters than other types of mass movements. This is probably due to the high mobility (and velocity) and long runout of these loess slides and flows (note the Kainama loess flow has a length of about $1 \mathrm{~km}$, for a volume of about $0.5 \times 10^{6} \mathrm{~m}^{3}$ while the neighbouring mixed slides have a much larger volume for a similar length). The high impact potential of loess landslides is increased if the main trigger event occurs suddenly, such as an earthquake. Even though earthquake-triggered loess slides and flows are far less frequent than rainfall triggered ones, they caused much larger disasters in recent history, such as those triggered, respectively, by the 1949 Khait and the 1989 Gissar earthquakes in Northern Tajikistan (presented below in this section). Such earthquake-triggered loess landslides also strongly contributed to one of the most catastrophic earthquake events worldwide, the $\mathrm{M}=8.5$ Haiyuan-Gansu (China) earthquake in 1920. Zhang and Wang (2007) referring to Close and McCormick (1922), reported that about 100,000 people (near $50 \%$ of total death toll) were killed by landslides in loess deposits.

Other prominent examples of large pure loess landslides are the $4 \mathrm{~km}$ long Kochkor-Ata landslide (volume of $10 \times 10^{6} \mathrm{~m}^{3}$ according to Roessner et al., 2005; we estimate that the volume is smaller: $6.5 \times 10^{6} \mathrm{~m}^{3}$, see Table 3 ) and near the Northern border of the Fergana Basin (Fig. 6a) as well as the loess flows in the Kokjangak region (Fig. 6d). The Kochkor-Ata landslides occurred in April 1994 when it killed one person. As for the Kainama site shown above, pre-event images show clear signs of instability well before the main activation. In particular, the Corona image of 1989 in Fig. 6a also shows a small lake below the existing scarp that was used to feed cattle. According to local population this lake had disappeared a few days before the landslide was activated in 1994.

Another indirect contribution to instability could have been the Ms = 6.2-6.3 Kochkor-Ata earthquake in 1992 that occurred at $17 \mathrm{~km}$ south of the landslide site. A more direct effect of this earthquake was the increased landslide activation in the neighbouring Maily-Say Valley in 1992.

In this valley, more than 200 landslides can now be identified over an area of 10 by $10 \mathrm{~km}$, some with disastrous impacts (river damming and flooding - see Havenith et al., 2003 and the companion paper Havenith et al., in this issue - as well as direct impacts on the population - see Table 2). Here, pure loess flows are less common than mixed landslides, but some of them involve a significant amount of loess material that is deposited in the upper parts of the slopes. Thus, half of the landslides outlined in Fig. 6c near Maily-Say are partly or composed of loess material entirely (such as the westernmost one,
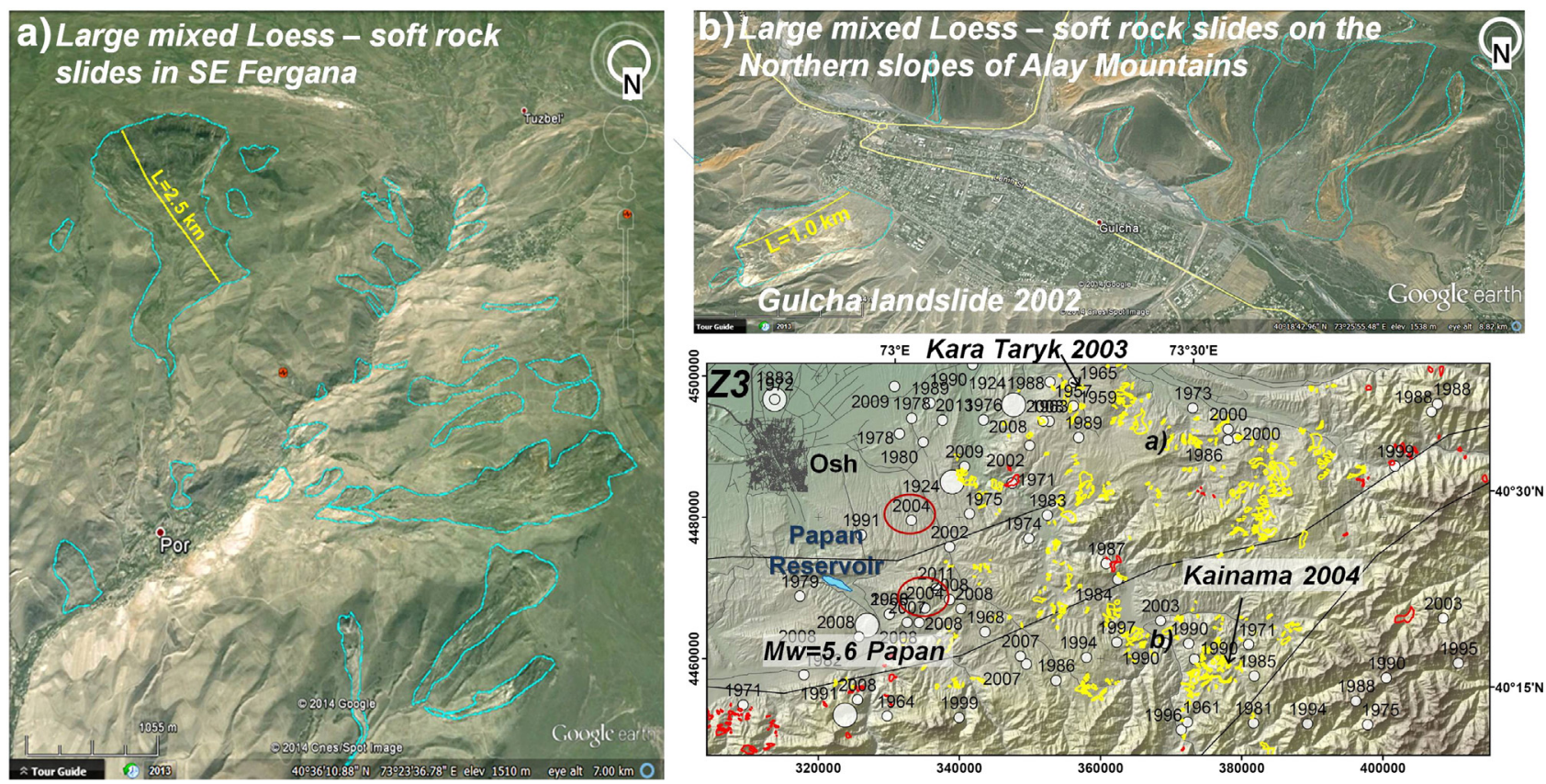

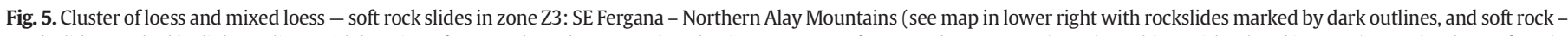

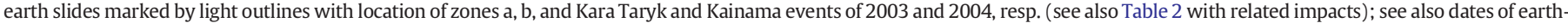

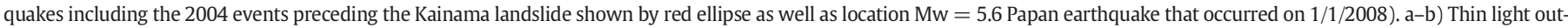

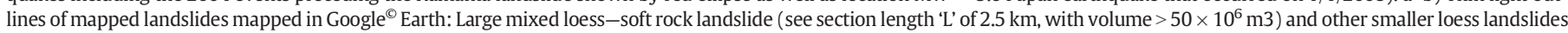
(a) and landslides in Mesozoic deposits (likely also involving loess material) around the town of Gulcha with location of 2002 landslide activation $>10 \times 10^{6}$ m3 (b). 

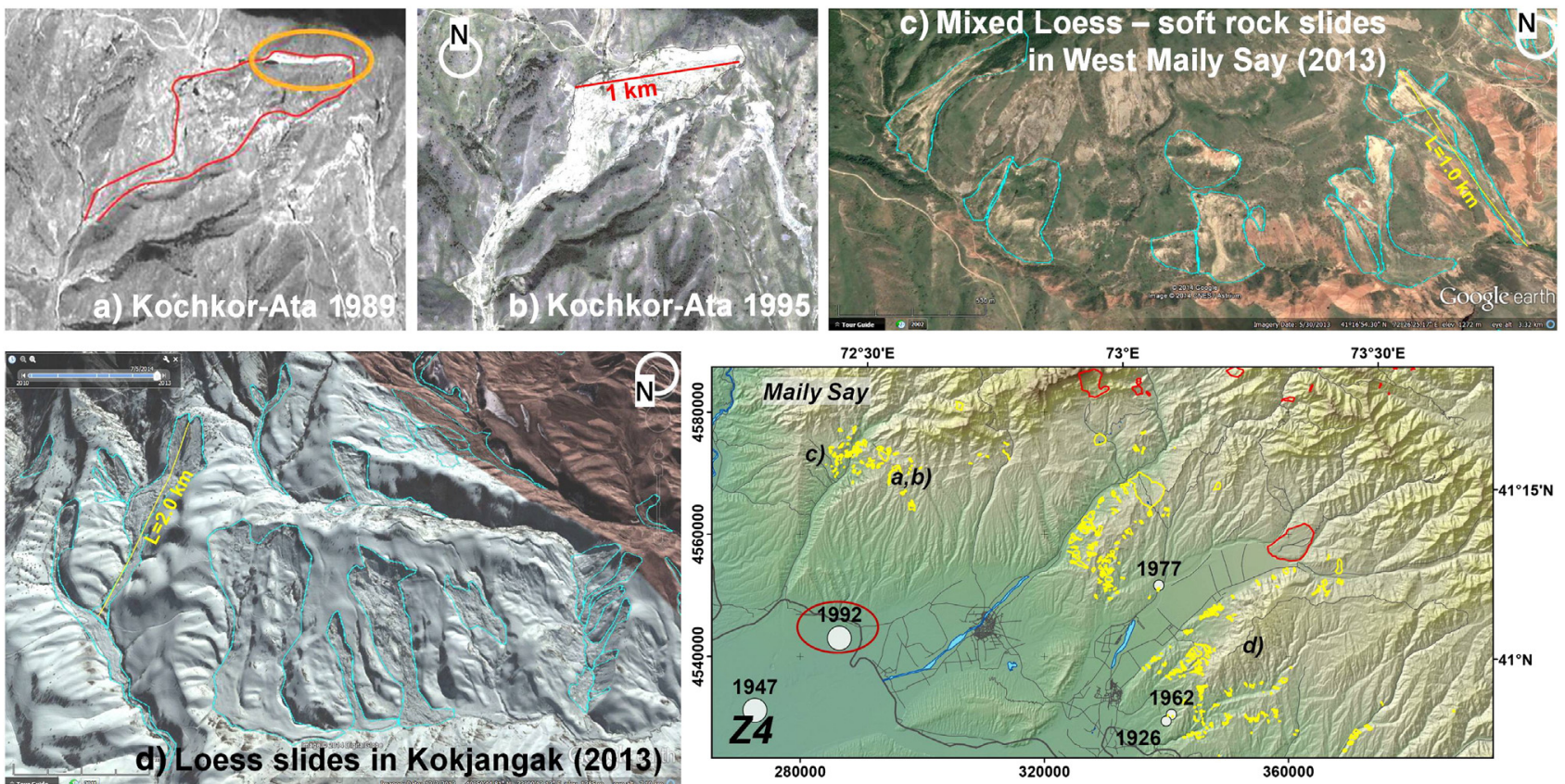

$73^{\circ} \mathrm{E}$

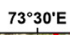

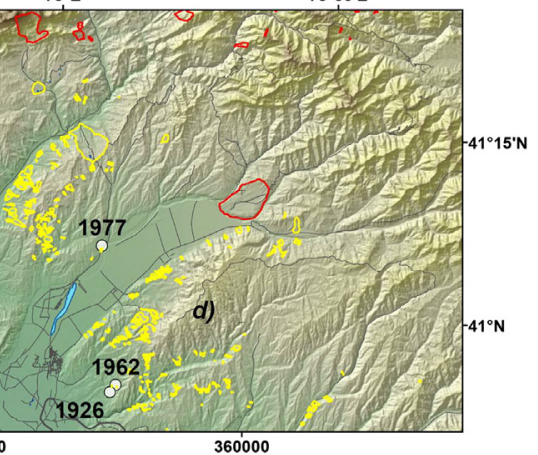

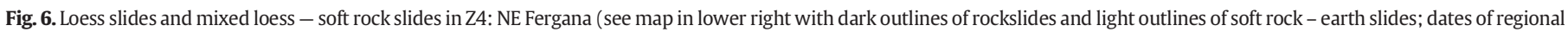

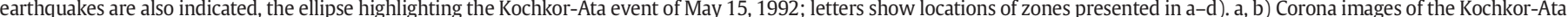

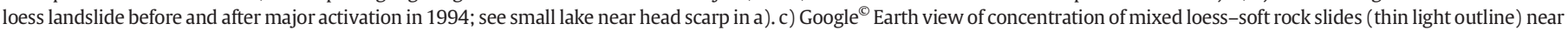

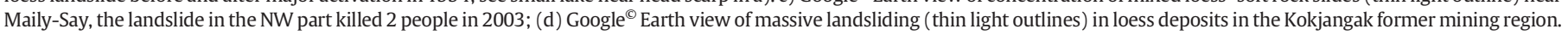

which killed two people in 2003 - it can be noticed that this event is not part of the official table of landslide victims (reproduced in Table 2); this and other examples show that probably less than $50 \%$ of the impacts have been recorded).

One of the highest concentrations of large loess flows in the Tien Shan can be found in the NE border of the Fergana Basin in the former coal mining area of Kokjangak (Fig. 6d). Some of the flows have total length of more than $4 \mathrm{~km}$. Here, we estimate that the former mining activity contributed to slope instability.

\subsection{Earthquake disasters and earthquake-triggered landslides}

The (likely) most severe natural disaster that ever hit the Tien Shan (at least within a mountain region) was the Ms $=7.4$ Khait earthquake in 1949. Earliest studies of this event include the ones of Gubin (1960) and Leonov (1960). The most catastrophic triggered mass movement is a rock avalanche that had buried the villages of Khait and Kusurak with thousands of inhabitants (Fig. 7c); however, the exact number of fatalities will never be known since during Soviet times there was
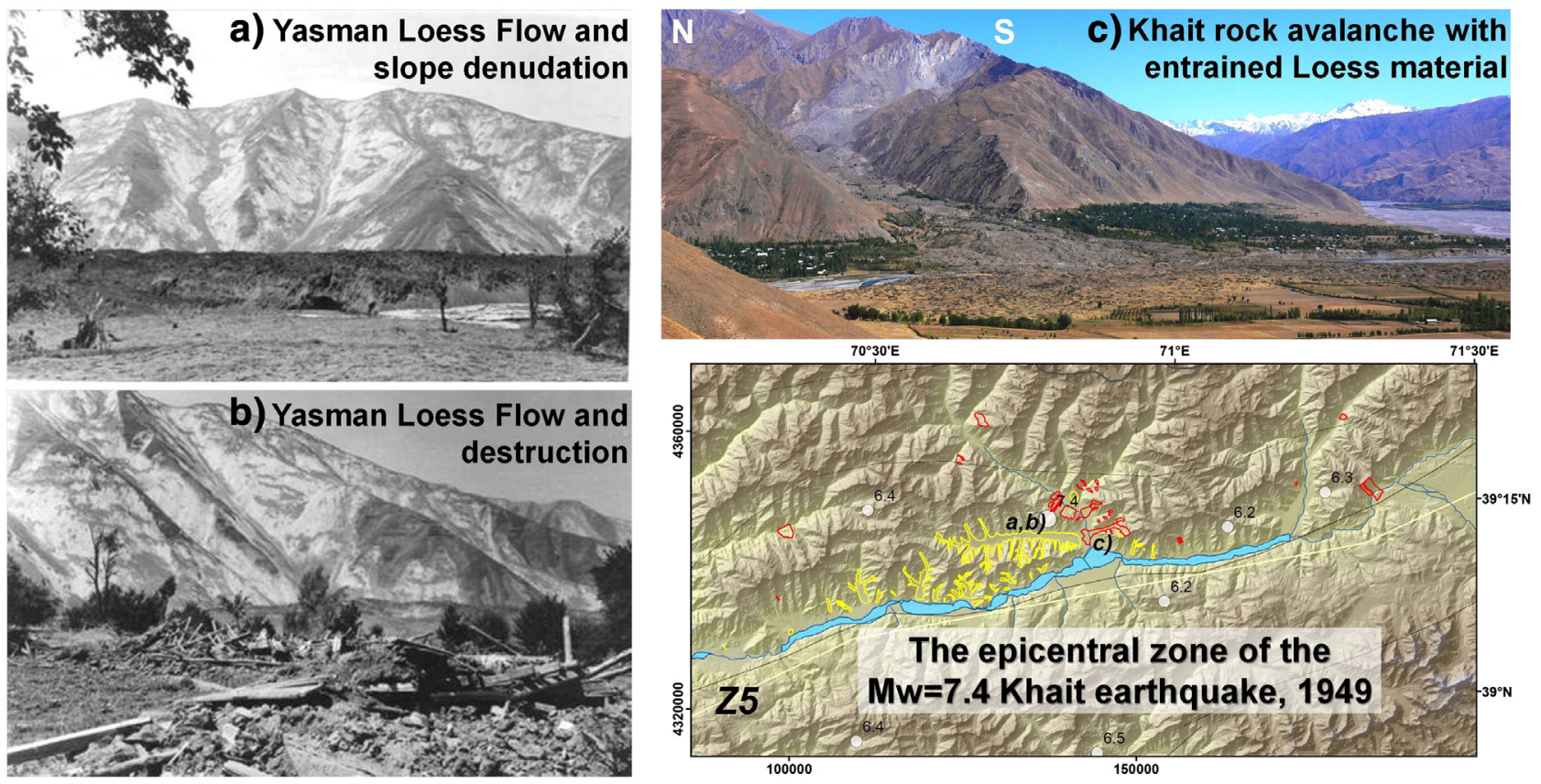

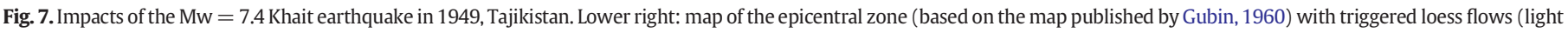

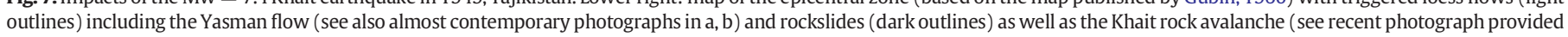
by S. Evans in c). 
restricted permission to publish exact numbers of victims due to natural disasters (Yablokov, 2001).

This rock avalanche had been triggered from Borgulchak Mountain at an altitude of about $2950 \mathrm{~m}$ and travelled more than $6 \mathrm{~km}$ before reaching the inhabited valley at an altitude of $1550 \mathrm{~m}$. The volume was initially estimated to more than $20010^{6} \mathrm{~m}^{3}$ (Leonov, 1960). However, more recent investigations by Evans et al. (2009) indicated that the total volume would be much lower, of about $75 \times 10^{6} \mathrm{~m}^{3}$ (our estimate is similar, of about $80 \times 10^{6} \mathrm{~m}^{3}$, see Table 3). Also both Leonov (1960) and Evans et al. (2009) observed that a significant part of the mass movement was made of loess, which probably contributed to the mobility of the initial rockslide. They also indicate that in the Yasman valley opposite to the Khait rock avalanche, massive loess earth flows are believed to have buried about 20 villages (see map of the epicentral area with outlined triggered mass movements in Fig. 7 and old photographs in Fig. 7a,b). In total, the Khait rock avalanche and loess earth-flows are likely to have killed more than 10,000 people during the 1949 event (about 7000 according to Evans et al., 2009; and estimates up to 28,000 according to Yablokov, 2001).

More recently, in 1989, the Gissar earthquake had triggered a series of earth-flows in loess in the South of Dushanbe (location in Fig. 3). At least 200 people were killed and hundreds of houses were buried (see buried houses in Fig. 8b). According to Ishihara et al. (1990), those slides were all related to extensive liquefaction, associating the liquefaction to the 'collapsible nature' of the highly porous loess material. The largest landslide, called 'Okuli' (Fig. 8a), had an estimated volume of $20 \times 10^{6} \mathrm{~m}^{3}$; this volume might even be larger according to our recent estimates (up to $30 \times 10^{6} \mathrm{~m}^{3}$, Table 3 ). However, the most catastrophic consequences were due to a smaller landslide that originated on the northern side of the same ridge and buried the village of Sharora with most of its inhabitants $(>200)$. The sliding surface of most landslides was located at a depth of about $15 \mathrm{~m}$ within the saturated part of the $30 \mathrm{~m}$ thick loess deposits (which would need to be involved entirely in the Okuli landslide if a volume of $>30 \times 10^{6} \mathrm{~m}^{3}$ is assumed for that one).

The second zone presenting a series of landslides triggered recently (last century) and directly by earthquakes is located along the Northern
Tien Shan. The best known examples are giant rockslides near well expressed fault scarps (see location in Fig. 3) triggered by one of the largest earthquakes that ever hit the Tien Shan mountains (in historic times): the Kemin Ms = 8.2 earthquake of 1911 (January 3). It was first analysed by Bogdanovich et al. (1914b). The earthquake caused extensive landsliding along the activated fault segments over a length of $200 \mathrm{~km}$ (Havenith et al., 2003). The largest mass movements were three rockslides, one within the Kemin valley (the Kaindy one), another one north of the lake Issyk-Kul (the Ananevo) and the third one in the upper reaches of the Chilik River valley at $43.02^{\circ} \mathrm{N}, 78.16^{\circ} \mathrm{E}$ in the present-day Kazakhstan. The first one, the Kaindy rock avalanche (about $15 \times 10^{6} \mathrm{~m}^{3}$ ) composed of limestone material occurred along the activated Chon Kemin fault at about $60 \mathrm{~km} \mathrm{~W}$ of the epicentre (Havenith et al., 2003; see fault location marked by yellow line and rockslide in Fig. 8e), and is known to have buried a village of yourts with 38 inhabitants; the second is the 'Ananevo' rockslide (Fig. 8d) located in the north of Lake Issyk Kul (at some $80 \mathrm{~km}$ east of the presumed epicentre). Failure took place at the southern end of a mountain ridge, just above the discontinuous Chon Aksu Fault also activated by the 1911 Kemin earthquake (Havenith et al., 2003; see also fault location marked by yellow line in Fig. 8d). According to Delvaux et al. (2001), this section of the Chon Aksu fault is a thrust gently dipping towards the northeast into the collapsed slope. Evidence of the presence of the fault is the related scarp with a height of $1 \mathrm{~m}$ at $3 \mathrm{~km}$ WNW of the site increasing up to almost $10 \mathrm{~m}$ at $12 \mathrm{~km}$ to the WNW (see also multiple event scarp of Chon Aksu Fault damming a lake in the same valley in Fig. 8c). On the site itself, outcrops at the foot of the southwestoriented slope show particularly disintegrated and weathered granitic rocks within a 100-200 m thick fault zone. The third rockslide 'Chilik' had dammed the river course temporarily, but no data about the subsequent outburst flood have been reported.

\section{Landslide size-frequency distributions and correlations}

Landslide size-frequency statistics are based on the surface areas of 3436 landslide outlines (the total number of 3462 minus the 26 loess flows copied from Gubin, 1960). In addition, we present also the same
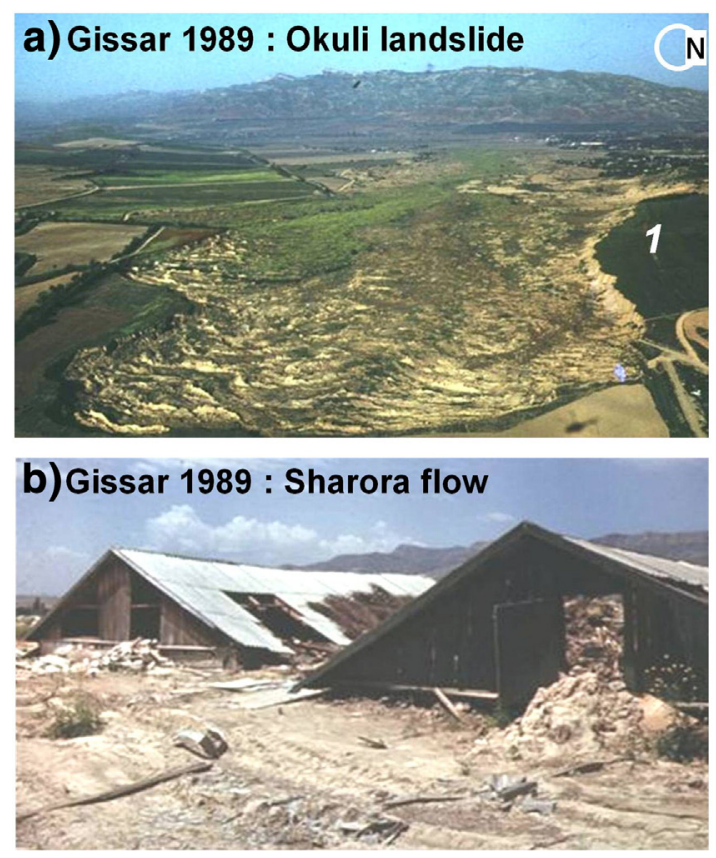
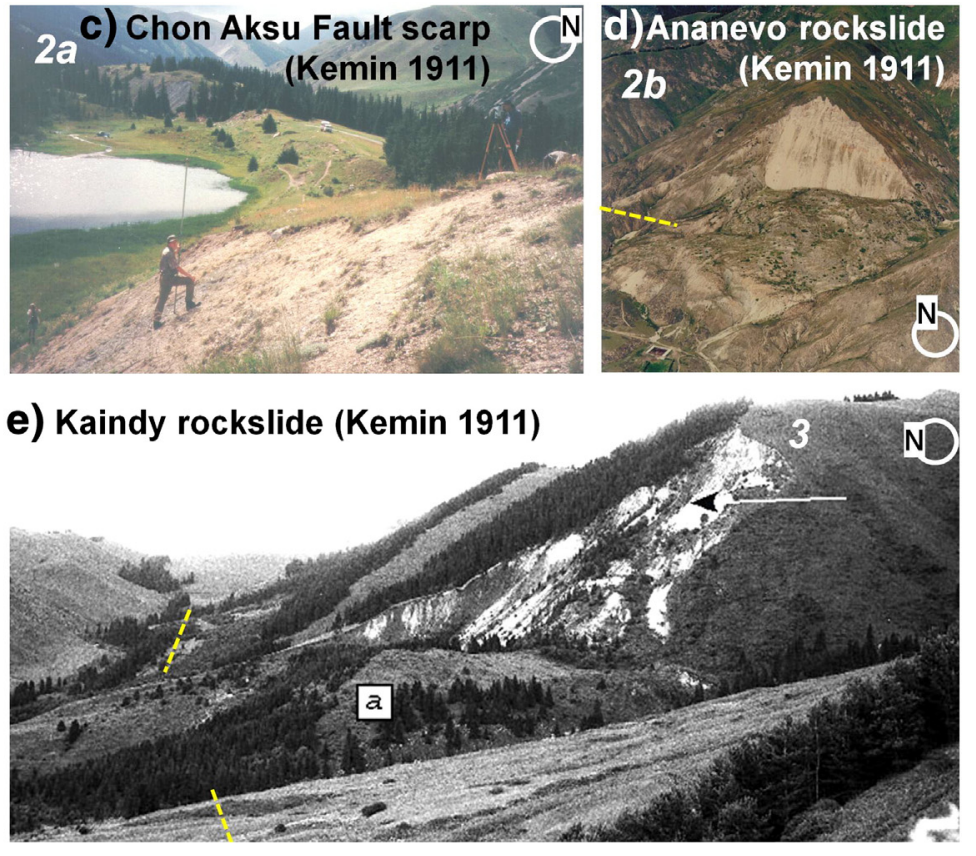

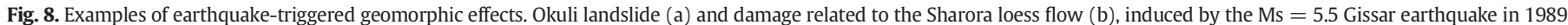

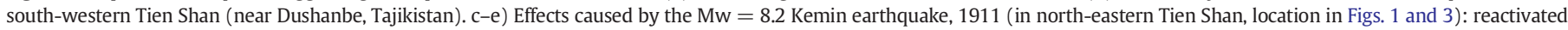

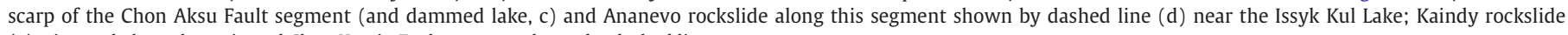
(e) triggered along the activated Chon Kemin Fault segment shown by dashed line. 
statistics for landslide volumes and consider also differences between size-frequency statistics of all landslides and separately soft rock earth slides and rockslide. Therefore, we developed an empirical formula to infer landslide volume from the surface area and the general geometry of the outline.

\subsection{Landslide surface area, thickness, volume}

The surface areas of all 3462 mapped mass movements were computed using the corresponding tool in ArcGIS 10.2. As landslide researchers are also interested in the volume of a mass movement, we tried to establish equations allowing us to infer the volume from the surface area considering an empirically defined maximum thickness. These estimates are compared with mass movements that had been studied in detail in the field by geophysical methods (electrical resistivity tomography and seismic tomography measurements locally calibrated by shallow trenches; see Havenith et al., 2000, 2003) and for which we have good thickness and volume estimates (with an uncertainty of about $10 \%$ with respect to the average values). From this field experience we know that compact landslides (slumps, block slides) with a large surface area compared to their elongation are generally the thickest ones. Long runout rock avalanches or earth flows are comparatively much thinner. These characteristics are also true for soft rock or earth slides. Here, the perimeter of the outline is used as basic parameter to compute the elongation factor as is takes into account possible multiple sources of landslides and debris spreading in different direction, which may not be represented by a simple maximum length estimate of the landslide outline. The geometric calculation tool implemented in ArcGIS that is used for surface area determination also allows us to compute the outline (polygon) perimeter.

The elongation factor was calculated (see Eq. (3)) considering the ratio between the perimeter of an ideally compact (least elongated) mass movement with circular shape having the same surface area as the initial outline and the actual perimeter of the outline. For the maximum ratio of 1 , the mapped mass movement can be considered as not elongated with respect to a circle (high values show a relative compact geometry), while very low values indicate a very strong elongation. loess flows and rock avalanches typically have an elongation factor of 0.2 to 0.7 (e.g., 0.42 for the Kochkor-Ata loess flow in Fig. 6b; 0.39 for the Khait rock avalanche shown in Fig. 7 above), while slumps and compact rockslides (with small runout) have an elongation factor of more than 0.8 (e.g., 0.83 for the mixed slide of Gulcha in Fig. 5b; 0.9 for the Ananevo rockslide in Fig. 8d). Some extremely small elongation values were obtained for the Yasman earthflow (0.13) due to the long runout and the multiple source zones, while the largest rockslides in the Tien Shan (Sary-Chelek, Beshkiol) have limited elongation marked by high ratios of more than 0.7 .

$\mathrm{Ef}=\frac{\left(2 \pi \sqrt{\frac{\mathrm{Sa}}{\pi}}\right)}{\text { Per }}$

(3- Elongation factor 'Ef')

where 'Sa' is the surface area of the entire polygon and 'Per' its perimeter. The part in brackets represents the perimeter of an ideally circular polygon with the same surface area as the actual polygon.

The maximum thickness of each mass movement was estimated on the basis of this elongation factor and the surface area of the respective outline using the empirical Eq. (4) below. The general empirical Eq. (4) was then adapted to the two different types of mass movements, rockslides and soft rock - earth slides as we noticed that a single formula was not specific enough to provide good estimates of both thickness and volumes for both types. The principal concept is to use the 'surface area scaling component' to compute the thickness: by comparing with known thickness and volume data we could observe that the thickness increases proportionally with the square root of the surface area; this effect is reduced by the elongation (increases with the elongation factor or the compact geometry to a factor of roughly 1.5 ). An empirical multiplication of $1 / 10$ was defined to fit results to known thickness and volume data. We noticed that the scaling factors are slightly enhanced for rockslides ('Sa' to the 0.52 instead of 0.5 and 'Ef' to the 2 compensated by a smaller multiplication factor of $1 / 12$, see Eq. (4a) below) while the surface area scaling is slightly attenuated for soft rock - earth slides ('Sa' to the 0.48 instead of 0.5 , see Eq. ( $4 \mathrm{~b}$ ) below). The stronger 'scaling effect' of rockslides compared to earth slides can be explained by the fact that for failures in rocks the thickness can almost increase 'indefinitely' with the surface area (a maximum thickness of several hundred metres is known for the largest rockslides in the Tien Shan) while the thickness values of earth slides, soft sediment slides or flows strongly depend on the presence of a soft layer with a generally limited thickness (e.g., for the Okuli landslide shown above we know that the calculated thickness of $45 \mathrm{~m}$ is exaggerated as the thickness of the activated loess layer in this area does not exceed $30-40 \mathrm{~m}$ ).

$$
\begin{aligned}
& \mathrm{mT}=\frac{\sqrt{\mathrm{Sa}} \mathrm{Ef}^{1.5}}{10} \quad(4-\text { maximum thickness for landslides ' } \mathrm{mT} \text { ') } \\
& \mathrm{mT}=\frac{\mathrm{Sa}^{0.52} \mathrm{Ef}^{2}}{12} \quad(4 \mathrm{a}-\text { maximum thickness for rockslides ' } \mathrm{mTr} \text { ') } \\
& \mathrm{mT}=\frac{\mathrm{Sa}^{0.48} \mathrm{Ef}^{1.5}}{10} \\
& (4 \mathrm{~b}-\text { maximum thickness for soft rock - earth slides 'mTe') }
\end{aligned}
$$

where 'Sa' is the surface area of the polygon and 'Ef' is the elongation factor (see Eq. (3)). The empirical estimate of the maximum thickness 'mT' (specifically 'mTr' for rockslides, 'mTe' for soft rock - earth slides) is supposed to represent the average thickness of at least $20-30 \%$ of the thickest part of the mass movement body.

Results of thickness calculation (based on trial and error tests) are compared with data available for a series of landslides (presented in Table 3), which had been investigated by using geophysics: the Suusamyr landslide, previous estimate of $30 \mathrm{~m}$, calculated value of $20.1 \mathrm{~m}$; the Kainama loess flow, previous $12 \mathrm{~m}$, calculated $13.9 \mathrm{~m}$; the Koytash landslide, previous $30 \mathrm{~m}$, calculated $30.6 \mathrm{~m}$; the Tektonik landslide, previous $25 \mathrm{~m}$, calculated $18.1 \mathrm{~m}$; the Bielogorka rock avalanche 1 , previous $50 \mathrm{~m}$, calculated $48.4 \mathrm{~m}$; and the Ananevo rockslide, previous $60 \mathrm{~m}$, calculated $76.5 \mathrm{~m}$. These comparisons show that the method does not reproduce the exact value of previously measured thickness, but does neither systematically over- nor underestimate these values. We are aware that the developed model should be calibrated by a larger number of known thickness values, but which are at present not available for the target area. Comparisons should be made with data from other mountain regions.

In order to finally compute the volume of the landslides, another simple empirical Eq. (5) was defined on the basis of the surface area and the maximum thickness (the same equation for rockslides and soft rock - earth slides):

$\mathrm{V}=\frac{\mathrm{Sa} \times \mathrm{mTr}, \mathrm{e}}{3}$

(5- Volume 'V')

where 'Sa' is the surface area of the polygon and 'mTr,e' the maximum thickness estimated according to Eq. (4), (4a), and (4b), respectively for rockslides ( $r$ ) and for soft rock - earth slides (e).

This coefficient ' $1 / 3$ ' was used considering an average thickness of $50 \%(=$ factor of $1 / 2)$ of the maximum thickness of $2 / 3$ of the entire mass movement outline, which actually represents its body (or deposition area - considering that on average $30 \%$ of the polygon covers the scarp area): factor of $1 / 3=1 / 2 * 2 / 3$. The resulting volume estimates 
generally deviate less than 30\% from the previously estimated volumes (shown in Table 3).

It should be noted that this first attempt to derive thickness and volume estimates based on the geometry of the landslide only considers a very rough definition of the type of the landslide (rockslide versus soft rock - earth slides). The first improvement would be to adapt the equations to a more specific type of landslide. For instance, we consider that the volume (and thus also the thickness) of many loess flows can be overestimated: the largest overestimate was obtained for the Okuli loess flow (see also explanation above related to the limited layer thickness): $30 \times 10^{6} \mathrm{~m}^{3}$ versus previously estimated $20 \times 10^{6} \mathrm{~m}^{3}$. However, it can also be noted that the volume estimate for the Kochkor-Ata loess landslide $\left(6.8 \times 10^{6} \mathrm{~m}^{3}\right)$ is well below the previously estimated volume of $10 \times 10^{6} \mathrm{~m}^{3}$ (Roessner et al., 2005) while the volumes of many rockslides could be underestimated (using Strom, 2010, as reference, see Table 3). Good fits compared to previous estimates by Strom (2010) were obtained for the largest known rockslides in the Tien Shan: Sary-Chelek (previously estimated at more than $6 \mathrm{~km}^{3}$, here calculated at $7.7 \mathrm{~km}^{3}$ ) and Beshkiol (previously $10 \mathrm{~km}^{3}$, newly calculated $\left.11.0 \mathrm{~km}^{3}\right)$.

\subsection{Size-frequency relationships}

Size-frequency relations (Fig. 9) were computed for 3436 landslide outlines (all besides the Khait loess flows) in terms of probability density function (PDF) both for the measured surface areas $\mathrm{p}\left(\mathrm{A}_{\mathrm{L}}\right)$ and the inferred volumes $\mathrm{p}\left(\mathrm{V}_{\mathrm{L}}\right)$. The same statistics were computed separately for 1389 mapped rockslides and 1807 soft rock landslides. Therefore, we use the method introduced by Malamud et al. (2004) for surface areas (Eq. 6) and adapting it for volumes (Eq. 7):

$\mathrm{p}\left(\mathrm{A}_{\mathrm{L}}\right)=\frac{1}{\mathrm{~N}_{\mathrm{LT}}} \frac{\delta \mathrm{N}_{\mathrm{L}}}{\delta \mathrm{A}_{\mathrm{L}}}$

$\mathrm{p}\left(\mathrm{V}_{\mathrm{L}}\right)=\frac{1}{\mathrm{~N}_{\mathrm{LT}}} \frac{\delta \mathrm{N}_{\mathrm{L}}}{\delta \mathrm{V}_{\mathrm{L}}}$

where $\delta N_{L}$ is the number of landslides with areas (volumes) between $A_{L}$ $\left(V_{L}\right)$ and $A_{L}+\delta A_{L}\left(V_{L}+\delta V_{L}\right), N_{L T}$ being the total number of considered landslides. Surface areas were calculated in $\mathrm{km}^{2}$ and corresponding volumes in $\mathrm{km}^{3}$. It should be considered that we applied this method to a landslide catalogue - without time information for most mass movements - while Malamud et al. (2004) had developed the technique to assess size-frequency statistics of specific landslide events well delimited in time.

In a log-log graph (Fig. 9), this function shows the well known sizefrequency behaviour of natural phenomena and geomorphic or tectonic features (e.g., earthquakes, landslides, faults) whose number decreases with increasing size according to a power law (Turcotte, 1997). In this regard, Stark and Hovius (2001) further state that '...that the number of observed landslides is a negative power function of the landslide size, across some size range. This inference holds true ... and whether the landslides are triggered over a long period of time or almost instantaneously..., which indicates that this technique can well be applied to landslide catalogues that do not necessarily contain data from specific events.

The generally observed 'roll-over' for smaller events (i.e., decreasing number with decreasing size) is only partly seen here, because the inventory was not completed for landslides with surface areas smaller than $1000 \mathrm{~m}^{2}$ (due to resolution problems) where this roll-over typically appears (see Malamud et al., 2004). Therefore, here, we will only consider the linear 'tail' of the size-frequency relationships which appears for surface areas larger than $10^{5} \mathrm{~m}^{2}$ or $0.1 \mathrm{~km}^{2}$ (or for volumes larger than $10^{6} \mathrm{~m}^{3}$ or $0.001 \mathrm{~km}^{3}$ ). Above these thresholds, a good fit between the probability density values and a power law can be obtained (coefficient of determination $R^{2}$ of 0.99). The power laws and corresponding fits $\left(R^{2}\right)$ are indicated in Fig. 9. The general form of this law is:

Power Law Function $=p($ unit $) \times(\text { area, volume })^{-(\rho+1)}$

where $p$ (unit) is the probability density value for a unit surface area (here $=1 \mathrm{~km}^{2}$ ) or unit volume (here $=1 \mathrm{~km}^{3}$ ), $\rho+1$ is the exponent, (area, volume) represents the ' $x$ '-variable, the surface area or the corresponding volume.

The $p$ (unit) coefficient indicates how many landslides have a surface area (or volume) close to $1 \mathrm{~km}^{2}\left(1 \mathrm{~km}^{3}\right)$ compared to the total number of landslides: for instance, the coefficient value of 0.0708 for the total number of considered landslides (3436) means that about 240 landslides $(=0.070 * 3436)$ in the inventory have a surface area close to

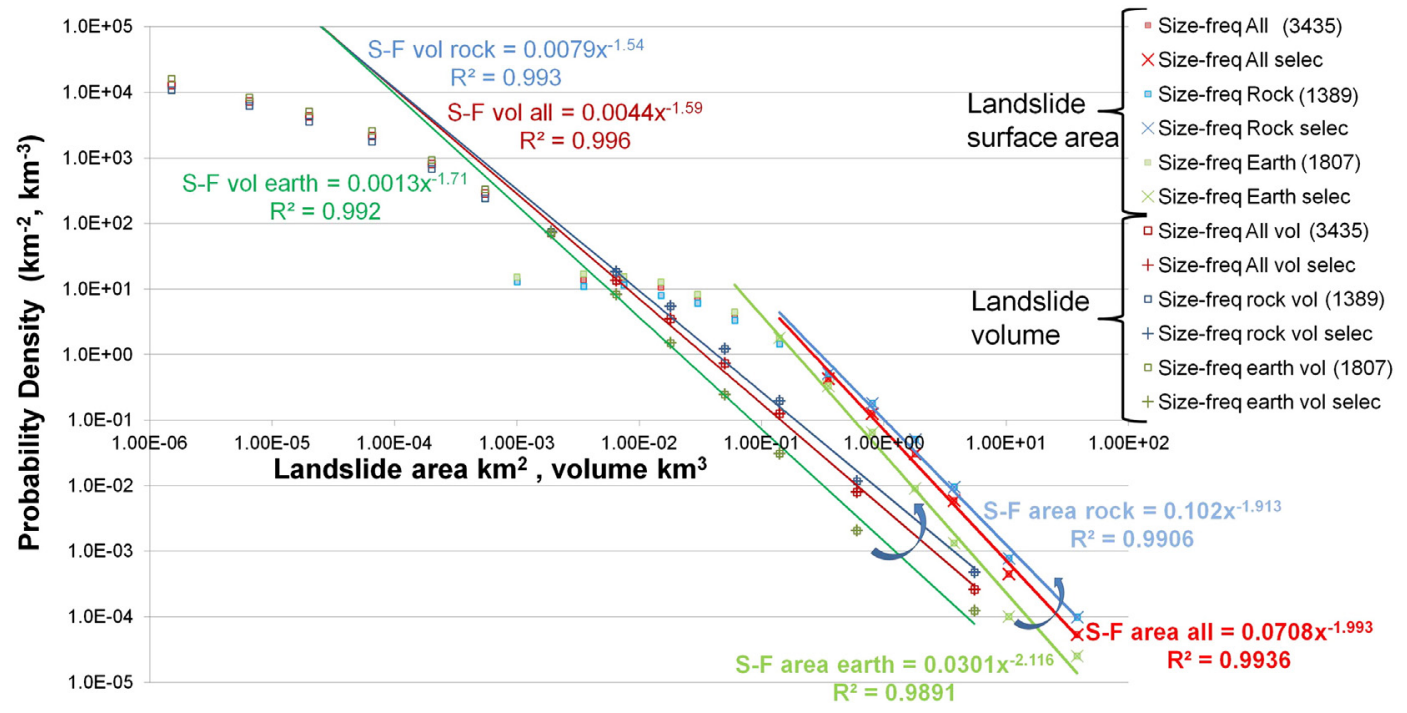

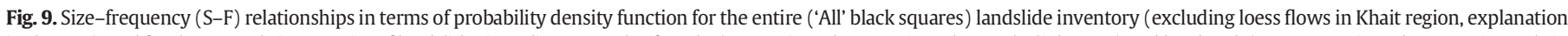

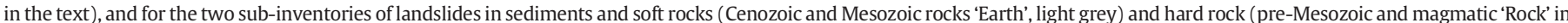

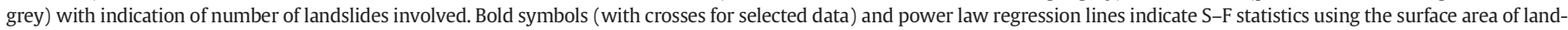

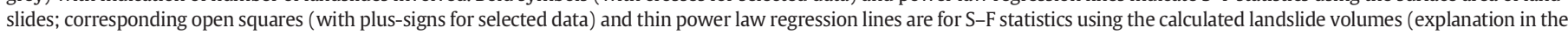
text, see also Table 3). 
$1 \mathrm{~km}^{2}$ (considering a certain interval) while the corresponding value for volumes, 0.0045 , indicates that only 15 landslides have a volume close to $1 \mathrm{~km}^{3}$. The exponent $-(\rho+1)$ provides information on the decay of landslide numbers with increasing size. The lowest values of $\rho+1$ are obtained for the rockslide inventory, 1.91 for surface areas (1.55 for volumes), medium values for the total inventory, 1.99 for surface areas (1.6 for volumes) and larger values for the soft rock - earth slides and flows, 2.11 for surface areas ( 1.7 for volumes). First, the systematically lower values of $\rho+1$ obtained for landslide volumes can be related to the combined increase of landslide surface area and thickness, stretching the data along the horizontal axis (landslide volumes) and thus decreasing the decay. Second, all exponent values show that, compared to the total number of landslides, rockslides tend to be larger than soft rock landslides (smaller decrease of number with increasing size of landslide). This is also confirmed by the direct data included in the inventory showing that most of the largest landslides with volumes exceeding $1 \mathrm{~km}^{3}$ are rockslides (13 out of 15 in the Kyrgyz and Tajik Tien Shan, other 7 landslides with a volume exceeding $1 \mathrm{~km}^{3}$ are located in other parts of the Tien Shan for which we do not have precise geological information).

A major issue related to size-frequency statistics is the completeness of the inventory (which may also affect the exponent of the power law decay). Here, we consider that beyond the area and volume thresholds used for the power law fits of, respectively, $10^{5} \mathrm{~m}^{2}$ and about $310^{6} \mathrm{~m}^{3}$, all or at least $90 \%$ of all landslides have been mapped within the target area. Actually, the entire landslide inventory had been cross-checked by three of the authors of this paper. However, we do not exclude that some landslide features might have been missed, first because they are very old and would require field investigation for recognition; second, because some areas are not covered by high resolution imagery above an altitude of $3000 \mathrm{~m}$; third, even where high mountain areas (>2500 $\mathrm{m}$ ) are covered by high resolution imagery, we met ambiguities to distinguish between landslide and moraine deposits. Nevertheless, we assume that such ambiguities equally affect medium and large-size mass movements and should therefore not have a significant impact on the size-frequency statistics.

\section{Discussion: linking landslide and earthquake statistics}

In Section 2 we showed that the return period of Mw $\geq 7$ earthquakes is about 10 to 20 years in the studied part of the Tien Shan; the highest probability of an occurrence (with return periods of roughly 100 years) is observed along the northern and the southern border of the mountain range. However, the most recent $M>7$ event in 1992 showed that large earthquakes can also occur in zones (here the central Tien Shan) where they were not expected according to previous earthquake statistics. According to the statistics presented in Fig. 2, an event with $\mathrm{M}>7$ is even less probable in the Fergana Basin that is marked by a relatively high low-magnitude seismicity (while the return period of $\mathrm{M}>7$ events is 500 to 1000 years). Nevertheless, such an occurrence is not impossible especially since two major fault structures crossing the Northern and Eastern part of the Fergana Basin have been identified (see Fig. 1; note, the Andizhan earthquake of 1902 most likely occurred along the eastern fault, see Fig. 3). Similar important neotectonic structures were identified in most parts of the Tien Shan. The largest one is the Talas-Fergana Fault crossing the entire mountain range over a distance of more than $600 \mathrm{~km}$ (its extent is even much larger outside the mountain range). It should be noticed that this fault has not produced any large earthquakes in recent times. The largest historical earthquakes $(\mathrm{M}>8)$ were produced by the $300 \mathrm{~km}$ long Chilik-Kemin Fault in the north-eastern Tien Shan. Along most of these major faults large surface ruptures and giant rockslides can be identified. However, the occurrence time of most of these rockslides (and often also of the fault scarp formation) is not known. It is estimated that many of them are at least 1000 years old. Thus, a direct link between large earthquake and giant landslide occurrence can only be proved for a few relatively recent cases such as the Ananevo and Kaindy rockslides triggered by the Kemin earthquake in 1911 (Fig. 8), the Khait rock avalanche and the Yasman flow triggered by the Khait earthquake in 1949 (Fig. 7), the Okuli landslide triggered by the Gissar earthquake in 1989 (Fig. 8), the Belaldy rock avalanche triggered by the Suusamyr earthquake in 1992. A seismic trigger for the Kara Suu rock avalanche 'sitting' on the Talas Fergana Fault is most likely but not proved.

Another indicator of the contribution of earthquakes to landslide activation can be analysed on the basis of the size-frequency analyses (note, a more detailed analysis of the spatial relationship between fault structure, earthquakes and landslides or landslide clusters is presented in the companion paper by Havenith et al., in this issue). First, we note the fact that the landslide PDFs shown in Fig. 9 produce decay exponents that are clearly larger $(\rho+1>1.5$ for volumes, $>1.9$ for surface areas) than the b-values obtained for the GRL presented in Fig. 2 (b-values between 0.7 and 1.2).

To explain this, we consider three basic differences between the GRL and PDF: first, for the PDF all events are counted per interval while for the GRL they are counted cumulatively ('larger than'); second, the units of the X-variable used for the PDF and GRL are different: for the landslide PDF, the surface area and the volume are used as reference units while for the GRL the earthquake magnitude is used; third, the time-component is not taken into account by the ' $\mathrm{N}$ ' number of landslides used for the PDF while for the GRL the number of seismic events per year is calculated. This additional time-component of the GRL function does not explain the lower b-value (compared to the PDF decay) as the division by a constant value (number of years) does not modify the decay exponent. The difference between cumulative GRL and noncumulative PDF function can neither be responsible for the observed changed exponent value as normally the cumulative law is marked by a steeper decay than the corresponding non-cumulative law (while here it is the opposite). Therefore, the generally lower b-values must be related to the changed $\mathrm{x}$-variable unit. In this regard, it was already shown that the decay exponent decreases if landslide volumes are considered as $\mathrm{x}$-variable instead of their surface area; thus, the increase in 'size' or dimension of the $x$-variable contributes to the decrease of the exponent value. The magnitude is a unit representing the full size of an earthquake, somehow also its energy - therefore, this additional size component of the magnitude $\mathrm{x}$-variable explains why the GRL has a lower decay exponent than the landslide PDF (even of those using the volume as $\mathrm{x}$-variable).

Having these general technical differences in mind, some more specific comparative observations can be made: rockslide size-frequency statistics are marked by the lowest (landslide PDF) decay exponent $(\rho+1=1.9)$ and rockslides are spatially clustered in areas where the seismicity is characterized by relatively low b-values ( 0.84 for the central Tien Shan and 0.7 for the northern Tien Shan); most of the rockslides with volumes larger than $1 \mathrm{~km}^{3}$ are located in these regions. Size-frequency statistics applied to soft rock - earth slides are marked by a higher decay exponent and these landslides are clustered around the Fergana Basin and along the southern Tien Shan where the seismicity is marked by higher b-values (reaching even 1.2 in the Fergana Basin, which can be considered as a near maximum possible b-value). As the time-factor is not considered for the landslide size-frequency statistics only qualitative comparisons can be made with earthquake statistics. Landslide occurrence is most frequent along the rim of the Fergana Basin (during some 'wet' years, several dozens or even more than 100 landslides can be activated), where also the relatively highest frequency of small earthquakes ( $\mathrm{M}<5$, large a-value) can be observed; a similar high frequency is also observed for climatic events - which shows that those landslides near the Fergana Basin are more controlled by climatic factors (see also Havenith et al., 2006b). Rough estimates of ages of large rockslides (see also Strom, 2010) in the central Tien Shan show that these mass movements are very infrequent, but their relative 'weight' compared to the occurrence of small landslides in this region is high just as for earthquakes in this region. 
Finally, it is also interesting to compare the presented landslide sizefrequency relationships with those known for other regions. Malamud et al. (2004) obtained for three different inventories (landslides triggered by the 1994 Northridge earthquake, by the Umbria snowmelt event in 1997 as well as those triggered by the Hurricane 'Mitch' in Guatemala in 1998) the same value of $\rho+1=2.4$. Stark and Hovius (2001) obtained similar values (2.44-2.48) for a landslide dataset from New Zealand and a smaller value (2.11) for a landslide data set from Taiwan (established before the 1999 Chi-Chi earthquake). Considering the relatively high values for the New Zealand landslide inventory (and partly also for Taiwan), they emphasized the important contribution of small landslides to regional slope instability. Now, it interesting to notice that Chen (2009) computed a value of 1.8 for the landslides triggered by the 1999 Chi-Chi earthquake in Taiwan. They further show that this exponent value increased for post-seismic landslide events triggered by typhoons in 2001 and 2004 to reach a level similar to the one obtained by Stark and Hovius (2001) for pre-earthquake landslide data from Taiwan ( 2.1). For our inventory an exponentvalue of 2.0 was determined, which is clearly smaller than the values obtained by Malamud et al. (2004) and Stark and Hovius (2001). This indicates that the proportion of large landslides is bigger in the Tien Shan compared, e.g., to the regions investigated by these latter authors. For recent earthquakes in the Tien Shan (e.g., Ms = 7.2 Suusamyr earthquake, 1992), we cannot establish quake-induced landslide sizefrequency relationships as only some dozens of mass movements had been triggered. However, it is interesting to notice that notwithstanding the small number of known seismically triggered mass movements, all $\mathrm{M}>7$ events of the last century in the studied part of the Tien Shan (and for which data are available: Kemin earthquake, 1911; Khait earthquake, 1949; Suusamyr earthquake, 1992) triggered at least one mass movement with a volume larger than $10 \times 10^{6} \mathrm{~m}^{3}$. These events show that the large $(M>7)$ earthquakes tend to induce a disproportional large number of big mass movements that may contribute to the lower decay exponent. A similar conclusion can be established for the Taiwan landslide data comparing the pre-1999-earthquake landslide statistics of Stark and Hovius (2001) with those related to the 1999 earthquake and the post-seismic events presented by Chen (2009): the lowest exponent value was obtained for landslides triggered directly by the Mw $=7.6$ Chi-Chi earthquake in 1999. Thus, especially for the sub-inventory of the rockslides in the Tien Shan, we can conclude that the relatively low exponent value of the power law decay can at least partly be attributed to seismic triggering.

\section{Conclusion}

In this paper we presented the core data of our geohazards database that was compiled for a large part of the Tien Shan range in central Asia: an updated earthquake catalogue as well as a new landslide inventory. In Sections 2 and 3 we outlined the high seismicity and the presence of numerous clusters of both rockslides in the higher mountains and earth slides near the basins. Therefore, it seems straightforward to establish a link between both geohazards - earthquakes and landslides, especially since climatic factors are attenuated (the general climate of the Tien Shan can be characterized as semiarid) compared to other mountain ranges such as the Alps. However, above we also showed that one important connection element is missing or insufficiently known: the time information. This time component is better known for earthquakes than for landslides, because seismic events can affect much larger regions and, therefore, $\mathrm{M}>6$ earthquakes were recorded almost continuously over more than one hundred years - while for landslide activations there is even no complete catalogue for the last 20 years. It should be noted that also for the larger earthquakes with long return periods the time information is not sufficient. Geological dates are only available for very few giant ancient rockslides (less than ten) and return periods of massive rockslides with, for instance, a volume larger than 0.1 or larger than $1 \mathrm{~km}^{3}$ are not known. In the discussion, we established links between earthquake and landslide size-frequency relationships. Here, such a link would mean that we can relate the return periods of such giant $1 \mathrm{~km}^{3}$ landslides (mainly rockslides) to the return periods of large $M>7.5$ earthquakes (none of the smaller earthquakes triggered such large mass movements - the largest known one is probably the Yasman Flow with a volume of more than $0.2 \mathrm{~km}^{3}$ that was triggered by the $\mathrm{Mw}=7.4$ Khait earthquake in 1949). However, without more dates for rockslides and also for $M>7.5$ earthquakes that have return periods of more than 50 years in the Tien Shan (probably more than 100 years if we consider the mountain areas only), we can only assume that for such giant rockslides the return period would be similar (more than 100 years for the mountain areas within the entire target region).

If we consider risk related to mega-events, we have first to ask questions concerning the probability of occurrence of major earthquakes in/ near the most populated areas. Thus, it is of prime importance to know if $M \geq 7$ earthquakes can occur in the densely populated Fergana Basin or not - historical information does not allow us to answer this question. One of the strongest earthquakes in this region was the Andizhan event in 1902 with an estimated magnitude of only 6.4 but which caused enormous damage and probably killed several thousand people - one can imagine that the impacts would be even considerably larger if a $\mathrm{M}>7$ earthquake hit the same area in present times. For other regions, the same questions are equally relevant: what happens if an earthquake similar to the Belovodsk event hits again the region of Bishkek that is now much more populated than it was in 1885; if events such as the Karatag earthquakes of 1907 occur again in (and even closer to) the region of Dushanbe. For the internal parts of the mountain range, the risk seems less high due to the generally lower population density. Here, the elements most at risk are large dams along the Naryn River Hydropower cascade and the Vakhsh-Surkhob Hydropower cascade, where now new dams are being built - one will be the tallest in the world: the Rogun Dam in Northern Tajikistan. Considering the Rogun Dam construction, the question will be: what happens if an event even larger than the Khait earthquake hits that area in near future; actually, the same major fault that produced the catastrophic earthquake in 1949 runs near the Rogun Dam construction site. Considering remote effects related to a failure of such a giant ( $350 \mathrm{~m}$ high) dam is an integral part of total risk calculations. However, remote effects of giant landslides possibly triggered by large earthquakes inside the mountain range - sometimes far from densely populated areas - are generally not considered in total earthquake risk assessment. Assessing such coupled natural hazards is indeed far more difficult than assessing single hazards and their direct impacts. The problem is that with each new consequential effect, the prediction uncertainty increases almost exponentially - especially also because additional natural triggers may be involved such as intense and/or long-lasting precipitation events, rapid snow melts. For an artificial dam we can at least assume that it is designed to withstand impacts of reasonably high earthquake shaking or even of fault rupture under the structure. For a natural dam formed by a new large landslide such an assumption cannot be made - and here we are missing another piece of crucial information that is automatically known for an artificial dam: the artificial dam site location is known, not the one of the next giant landslide (possibly triggered by the next large earthquake). Thus, for a full coupled earthquakelandslide hazard assessment we need to combine several types of probabilities (through multiplication or better through convolution): the spatial and temporal probabilities of occurrence of a major earthquake (or better of related shaking levels), the spatial and temporal probabilities of landslide occurrence (considering also its size) as well as the probability of occurrence of a landslide event of a certain size, runout and possibly also marked by a certain velocity. The two first types of probabilities are determined by seismic hazard assessment. Then, once we can clearly prove that the temporal probability of giant landslide occurrence can be connected with the one of major earthquake events, only the spatial probability of landslide occurrence (with its size) still 
needs to be defined. These spatial probabilities are typically computed through landslide susceptibility assessment - for the target region, a landslide susceptibility assessment is presented in the companion paper by Havenith et al. (in this issue). In order to assess the probability of landslide size and dynamics, numerical modelling is needed. Thus, full earthquake scenario modelling for mountain regions is a very complex process. However, several examples of the past showed that reliable predictions of 'domino effects' induced by earthquakes can save many lives. This was exemplified in recent times through the Tangjiashan rockslide dam event triggered by the $\mathrm{Mw}=7.9$ Wenchuan earthquake in 2008 (Yin et al., 2009). A catastrophic outbreak of the lake formed behind that dam might have hit several hundreds of thousands of people, living tens of kilometres away from the site - upon recommendation by experts, extensive remediation measures were undertaken to produce a controlled breach of the dam that allowed for a significant lowering of the lake level. These measures can be considered as successful as the controlled outbreak flood did officially not claim any victims. Assessing such coupled hazards even before the next $M \geq 7$ earthquake occurs is highly relevant for many areas in the Tien Shan, not only for major dam sites but for all areas where towns of villages are located downstream from potential landslide activation areas. In addition, remote hazards may also involve the mobilisation of mining waste and nuclear waste in active and former mining areas - related risk is also discussed in the companion paper by Havenith et al. (in this issue).

\section{Acknowledgements}

Part of this study has been supported by the Nato Science for Peace Project 983289 'Prevention of landslide dam disasters in the Tien Shan, LADATSHA', 2009-2012.

\section{References}

Abdrakhmatov, K.Ye., Havenith, H.-B., Delvaux, D., Jongmans, D., Trefois, P., 2003. Probabilistic PGA and arias intensity maps of Kyrgyzstan (Central Asia). J. Seismol. 7, 203-220.

Abdrakhmatov, K.Ye., Aldazhanov, S.A., Hager, B.H., Hamburger, M.W., Herring, T.A., Kalabaev, K.B., Makarov, V.I., Molnar, P., Panasyuk, S.V., Prilepin, M.T., Reilinger, R.E. Sadybakasov, I.S., Souter, B.J., Trapeznikov, Yu.A., Tsurkov, V.Ye., Zubovich, A.V., 1996. Relatively recent construction of the Tien Shan inferred from GPS measurements of present-day crustal deformation rates. Nature 384, 450-453.

Allen, M.B., Windley, B.F., Chi, Z., 1992. Palaeozoic collisional tectonics and magmatism of the Chinese Tien Shan, Central Asia. Tectonophysics 220, 89-115.

Behling, R., Roessner, S., Kaufmann, H., Kleinschmit, B., 2014. Automated spatiotemporal landslide mapping over large areas using RapidEye time series data. Remote Sens. 6, 8026-8055.

Bindi, D., Abdrakhmatov, K.Ye., Parolai, S., Mucciarelli, M., Grunthal, G., Ischuk, A., 2012 Seismic hazard assessment in Central Asia: outcomes from a site approach. Soil Dyn. Earthq. Eng. 37, 84-91.

Bogdanovich, K.I., Klark, I.M., Korolkov, B.Ya., Mushketov, D.I., 1914a. Earthquakes in the northern Tien-Shan. Mater. Geol. Stud. 89, 13-14 (in Russian)

Bogdanovich, K.I., Klark, I.M., Korolkov, B. Ya, Muchketov, D.I., 1914b. Earthquake of the 4th January 1911 in the northern districts of the Tien Shan. Trans. Geol. Comm. Ser. 89 (270pp., in Russian).

Bommer, J.J., Benito, M.B., Ciudad-Real, M., Lemoine, A., López-Menjívar, M.A., Madariaga R., Mankelow, J., Méndez De Hasbun, P., Murphy, W., Nieto-Lovo, M., RodriguézPineda, C.E., Rosa, H., 2002. The El Salvador earthquakes of January and February 2001: context, characteristics and implications for seismic risk. Soil Dyn. Earthq Eng. 22, 389-418.

Borisoff, B.A., Rogozhin, E.A., 1992. The Racha, Georgia, April 29, 1991 earthquake: results of geological investigations. J. Earthq. Pred. Res. 1, 115-126.

Burette, S., 2012. Mapping of Landslides and Correlations With Morphological Factors Based on Remote Sensing, Field Observations and Measurements in the Centra Tien Shan (Kyrgyzstan). (Master's Thesis in Geological Sciences), University of Liege, Belgium (112pp.).

Burtman, V.S., Skobolev, S.F., Molnar, P., 1996. Late Cenozoic slip on the Talas-Fergana fault, the Tien Shan, Central Asia. Geol. Soc. Am. Bull. 108, 1004-1021.

Chedia, O.K., 1986. Morphostructures and Neotectonic of the Tien Shan. Ilim Publishing House, Frunze (314pp., in Russian).

Chen, C.Y., 2009. Sedimentary impacts from landslides in the Tachia River Basin, Taiwan. Geomorphology 105, 355-365.

Close, U., McCormick, E., 1922. Where the mountains walked. Natl. Geogr. 41, 445-464.

Cobbold, P.R., Davy, P., Gapais, D., Rossello, E.A., Sadybakasov, E., Thomas, J.C., Tondji Biyo J.J., de Urreiztieta, M., 1993. Sedimentary basins and crustal thickening. Sediment. Geol. 86, 77-89.
Dadson, S.J., Hovius, N., Chen, H., Dade, B., Lin, J.C., Hsu, M.L., Lin, C.W., Horng, M.J., Chen, T.C., Milliman, J., Stark, C.P., 2004. Earthquake-triggered increase in sediment delivery from an active mountain belt. Geology 32, 733-736

Danneels, G., Pirard, E., Havenith, H.B., 2007. Automatic landslide detection from remote sensing images using supervised classification methods. Geoscience and Remote Sensing Symposium IGARSS 2007. IEEE, pp. 3014-3017.

Danneels, G., Bourdeau, C., Torgoev, I., Havenith, H.B., 2008. Geophysical investigation and numerical modelling of unstable slopes: case-study of Kainama (Kyrgyzstan). Geophys. J. Int. 175, 17-34.

de Marneffe, C., 2010. Cartographie et modélisation 3D de la géologie de la vallée de Mailuu-Suu, Tien Shan. (Master's Thesis in Geological Sciences), University of Liege, Belgium (96pp., in French).

Delvaux, D., Abdrakhmatov, K.E., Lemzin, I.N., Strom, A.L., 2001. Landslides and surface breaks of the 1911, Ms 8.2 Kemin earthquake, Kyrgyzstan. Russ. Geol. Geophys. 42, 1167-1177.

Deprez, R., 2012. Prospection géophysique et géomodélisation 3D du glissement de terrain et du bassin de retenue de Tuyuk-Suu, Minkush, Tien Shan kirghize. (Master's Thesis in Geological Sciences), University of Liege, Belgium (98pp., in French).

Dupont, B., 2011. Application of Microseismic Measurements and Geomodelling to the Study of Two Loess Landslides in the Valley of Faizabad, Northern Tajikistan. (Master's Thesis in Geological Sciences), University of Liege, Belgium (70pp.)

Evans, S., Roberts, N., Ischuk, A., Delaney, K.B., Morozova, G.S., Tutubalina, O., 2009. Landslides triggered by the 1949 Khait Earthquake, Tajikistan, and associated loss of life. Eng. Geol. 109, 195-212.

Fedorenko, V.S., 1988. Rockslides and Rockfalls and Their Prediction. Moscow State University Publishing House, Moscow (214pp., in Russian).

Golovko, D., Roessner, S., Behling, R., Wetzel, H.U., Kaufmann, H., 2014. GIS-based integration of heterogeneous data for a multi-temporal landslide inventory. In: Sassa, K., et al. (Eds.), Landslide Science for a Safer Geoenvironment, pp. 799-804.

Gorum, T., Fan, X.M., van Westen, C.J., Huang, R.Q., Xu, Q., Tang, C., Wang, G.H., 2011. Distribution pattern of earthquake-induced landslides triggered by the 12 May 2008 Wenchuan earthquake. Geomorphology 133, 152-167.

Gorum, T., van Westen, C.J., Korup, O., van der Meijde, M., Fan, X.M., van der Meer, F.D., 2013. Complex rupture mechanism and topography control symmetry of masswasting pattern, 2010 Haiti earthquake. Geomorphology 184, 127-138.

Griggs, G.B., Plant, N., 1998. Coastal bluff failures in the northern Monterey Bay induced by the earthquake. In: Keefer, D. (Ed.), The Loma Prieta, California, Earthquake of October, 17, 1989 - Landslides, USGS Prof. Paper 1551-C, pp. C33-C50.

Gubin, I.E., 1960. Patterns of Seismic Manifestations of the Tajikistan Territory (Geology and Seismicity). Academy of Sciences of USSR Publishing House, Moscow (464pp., in Russian).

Haberland, C., Abdybachaev, U., Schurr, B., Wetzel, H.-U., Roessner, S., Sarnagoev, A., Orunbaev, S., Janssen, C., 2011. Landslides in southern Kyrgyzstan: understanding tectonic controls. Eos Trans. AGU 92, 169.

Harp, E.L., Jibson, R.W., 1995. Landslides triggered by the 1994 Northridge, California, earthquake. Bull. Seismol. Soc. Am. 86, 319-332.

Harp, E.L., Wilson, R.C., Wieczorek, G.F., 1981. Landslides From the February 4, 1976, Guatemala Earthquake. USGS, Washington (44pp.).

Havenith, H.B., Bourdeau, C., 2010. Earthquake-induced landslide hazards in mountain regions: a review of case histories from Central Asia. Geol. Belg. 13, 135-150.

Havenith, H.B., Strom, A., Jongmans, D., Abdrakhmatov, K., Delvaux, D., Tréfois, P., 2003. Seismic triggering of landslides, Part A: field evidence from the northern Tien Shan. Nat. Hazards Earth Syst. Sci. 3, 135-149.

Havenith, H.B., Strom, A., Cacerez, F., Pirard, E., 2006a. Analysis of landslide susceptibility in the Suusamyr region, Tien Shan: statistical and geotechnical approach. Landslides 3, 39-50.

Havenith, H.B., Torgoev, I., Meleshko, A., Alioshin, Y., Torgoev, A., Danneels, G., 2006b. Landslides in the Mailuu-Suu valley, Kyrgyzstan: hazards and impacts. Landslides 3, 137-147.

Havenith, H.-B., Jongmans, D., Abdrakhmatov, K., Trefois, P., Delvaux, D., Torgoev, I.A., 2000. Geophysical investigations of seismically induced surface effects: case study of a landslide in the Suusamyr valley, Kyrgyzstan. Surv. Geophys. 21, 351-370.

Havenith, H.-B., Torgoev, A., Schlögel, R., Braun, A., Torgoev, I., Ischuk, A., 2015. Tien Shan geohazards database: landslide susceptibility and impacts. Geomorphology, Special Issue 'Geohazards Databases' (in this issue).

Hung, J.-J., 2000. Chi-Chi earthquake induced landslides in Taiwan. Earthq. Eng. Eng. Seismol. 2, 25-33.

Ishihara, K., Okusa, S., Oyagi, N., Ischuk, A., 1990. Liquefaction-induced flow slide in the collapsible loess deposit in Soviet Tajik. Soils Found. 30, 73-89.

Jibson, R.W., Keefer, D.K., 1989. Statistical analysis of factors affecting landslide distribution in the new Madrid seismic zone, Tennessee and Kentucky. Eng. Geol. 27, 509-542.

Jibson, R.W., Prentice, C.S., Borissoff, A., Rogozhin, A., Langer, C.J., 1994. Some observations of landslides triggered by the 29 April 1991 Racha earthquake, Republic of Georgia. Bull. Seismol. Soc. Am. 84, 963-973.

Kalmetieva, Z.A., Mikolaichuk, A.V., Moldobekov, B.D., Meleshko, A.V., Jantaev, M.M., Zubovich, A.V., 2009. Atlas of earthquakes in Kyrgyzstan. 978-9967-25-829-7.

Keefer, D.K., Manson, M.W., 1998. Regional landslide distribution and characteristics of landslides generated by the earthquake. In: Keefer, D. (Ed.), The Loma Prieta, California, Earthquake of October, 17, 1989 - Landslides, USGS Prof. Paper 1551-C, pp. C7-C32.

Khain, V.E., 1977. Regional geoterconics. Off-Alpine Europe and Western Asia. Nedra Publishers, Moscow (359pp., in Russian).

Khazai, B., Sitar, N., 2004. Evaluation of factors controlling earthquake-induced landslides caused by Chi-Chi Earthquake and comparison with the Northridge and Loma Prieta events. Eng. Geol. 71, 79-95. 
Korjenkov, A.M., Mamyrov, E., Omuraliev, M., Kovalenko, V.A., Usmmanov, S.F., 2004. Rock avalanches and landslides formed in result of strong Suusamyr (1992, M = 7,4 ) earthquake in the northern Tien Shan. Test structures for mapping of Paleoseismic deformations by satellite images. In: Buchroithner, M.F. (Ed.), High Mountain Remote Sensing Cartography VII (HMRSC VII), Institute for Cartography of the Dresden University of Technology, Kartographische Bausteine, Band 23, Dresden (19pp.).

Leonov, N.N., 1960. The Khait, 1949 earthquake and geological conditions of its origin. Proceedings of Academy of Sciences of the USSR. Geophys. Series 3, pp. 409-424 (in Russian).

Makarov, V.I., 1977. Newest tectonic structure of central Tien Shan. Proceedings of Geological Institute of RAS. vol. 307 (172pp., in Russian).

Malamud, B.D., Turcotte, D.L., Guzzetti, F., Reichenbach, P., 2004. Landslide inventories and their statistical properties. Earth Surf. Process. Landf. 29, 687-711.

Molnar, P., Tapponnier, P., 1975. Cenozoic tectonics of Asia: effects of a continental collision. Science $189,419-426$.

Mushketov, I.V., 1890. The Vernyi earthquake of 28/05 (9/06) 1887. Proceedings of Geological Committee 10, St. Petersburg (154pp., in Russian).

Owen, L.A., Kamp, U., Khattak, G.A., Harp, E.L., Keefer, D.K., Bauer, M.A., 2008. Landslides triggered by the 8 October 2005 Kashmir earthquake. Geomorphology 94, 1-9.

Petley, D., Dunning, S., Rosser, N., Kausar, A.B., 2006. Incipient landslides in the Jhelum Valley, Pakistan following the 8th October 2005 earthquake. Disaster Mitigation of Debris Flows, Slope Failures and Landslides. Universal Academy Press Inc., Tokyo, Japan, pp. 47-55.

Roessner, S., Wetzel, H.-U., Kaufmann, H., Samagoev, A., 2005. Potential of satellite remote sensing and GIS for landslide hazard assessment in Southern Kyrgyzstan (Central Asia). Nat. Hazards 35, 395-416.

Schlögel, R., 2009. Detection of Recent Landslides in Maily-Say Valley, Kyrgyz Tien Shan, Based on Field Observations and Remote Sensing Data. (Master's Thesis in Geological Sciences), University of Liege, Belgium (133pp.).

Schlögel, R., Torgoev, I., de Marneffe, C., Havenith, H.-B., 2011. Evidence of a changing distribution of landslides in the Kyrgyz Tien Shan, Central Asia. Earth Surf. Process. Landf. 36, 1658-1669.

Schultz, S.S., 1948. Analysis of newest tectonics and relief of the Tien Shan. Proceedings of the All-Union Geographic Society. New Series 3 (222pp., in Russian).

Schuster, R.L., Highland, L.M., 2001. Socioeconomic and environmental impacts of landslides in the western hemisphere. USGS Open-File Report 01-0276.
Stark, C.P., Hovius, N., 2001. The characterization of landslide size distributions. Geophys. Res. Lett. 28 (6), 1091-1094.

Strom, A.L., 2010. Landslide dams in Central Asia region. J. Jpn. Landslide Soc. 47, 309-324 Strom, A.L., 2012. Effects of rockslides and rock avalanches on hydropower schemes in the Naryn River valley. In: Eberhardt, E., Froese, C., Turner, A.K., Leroueil, S. (Eds.), Landslides and Engineered Slopes: Protecting Society From Improved Understanding. Proc. 11th ISL, Banff, Canada, 3-8 June, 2012, pp. 1867-1872.

Strom, A.L., Abdrakhmatov, K.E., 2009. International summer school on rockslides and related phenomena in the Kokomeren River valley, Tien Shan, Kyrgyzstan. In: Sassa, K., Canuti, P. (Eds.), Landslides - Disaster Risk Reduction. Springer-Verlag, Berlin Heidelberg, pp. 223-227.

Strom, A.L., Korup, O., 2006. Extremely large rockslides and rock avalanches in the Tien Shan, Kyrgyzstan. Landslides 3, 125-136.

Torgoev, A., Lamair, L., Torgoev, I., Havenith, H.-B., 2013. A review of recent case studies of landslides investigated in the Tien Shan using microseismic and other geophysica methods. In: Ugai, K., Yagi, H., Wakai, A. (Eds.), Earthquake-Induced Landslides, pp. 285-294.

Turcotte, D.L., 1997. Fractals and Chaos in Geology and Geophysics. Cambridge University Press, Cambridge (221pp.).

$\mathrm{Xu}, \mathrm{C} ., 2$ 2014. Preparation of earthquake-triggered landslide inventory maps using remote sensing and GIS technologies: principles and case studies. Geosci. Front. http://dx.doi org/10.1016/j.gsf.2014.03.004.

Xu, C., Xu, X.W., Yao, X., Dai, F.C., 2014a. Three (nearly) complete inventories of landslides triggered by the May 12, 2008 Wenchuan Mw 7.9 earthquake of China and their spatial distribution statistical analysis. Landslides. http://dx.doi.org/10.1007/s10346013-0404-6.

Xu, C., Shyu, J.B.H., Xu, X.W., 2014b. Landslides triggered by the 12 January 2010 Port-auPrince, Haiti, $\mathrm{Mw}=7.0$ earthquake: visual interpretation, inventory compiling, and spatial distribution statistical analysis. Nat. Hazards Earth Syst. Sci. 14, 1789-1818.

Yablokov, A., 2001. The tragedy of Khait: a natural disaster in Tajikistan. Mt. Res. Dev. 21, 91-93.

Yin, Y., Wang, F., Sun, P., 2009. Landslide hazards triggered by the 2008 Wenchuan earthquake, Sichuan, China. Landslides. http://dx.doi.org/10.1007/s10346-009-0148-5.

Zhang, D., Wang, G., 2007. Study of the 1920 Haiyuan earthquake-induced landslides in loess (China). Eng. Geol. 94, 76-88. 